\title{
Procedures for the Adoption of Rules of General Applicability: The Need for Procedural Innovation in Administrative Rulemaking*
}

\author{
Robert W. Hamilton $\dagger$
}

I.

\section{INTRODUCTION}

The Adminstrative Procedure Act (APA) establishes two alternative procedures for the promulgation of legislative-type rules of general applicability by administrative agencies. ${ }^{1}$ One procedure is set forth in the Administrative Procedure Act, 5 U.S.C. section $553^{2}$ which requires that (1) a notice of proposed rulemaking be published, (2) an opportunity be given to imterested persons to submit written or oral comment, and (3) the rules, when finally promulgated, include "a concise general statement of their basis and purpose." This section 553 procedure is often described as "informal" or "notice-and-comment" rulemaking and is applicable to the great bulk of grants of rulemaking authority to Federal agencies. In contrast, rules that "are required by statute to be made on the record after opportunity for an

* This Article is based on a report made by the author as a consultant to the Administrative Conference of the United States. The report was made to the Conference in June, 1972, in support of a recommendation made by the Conference's Committee on Ruleınaking. The views expressed in this Article are those of the author and have not been approved by the Committee or the Administrative Conference of the United States.

$\dagger$ Professor of Law, University of Texas at Austin; B.A. Swarthmore, 1952; J.D. University of Chicago, 1955.

1. The Administrative Procedure Act [5 U.S.C. $\$ 551(4)$ (1970)] defines a rule as an "agency statement of general or particular applicability and future effect designed to implement, interpret or prescribe law or policy ..." This Article is directed to the developinent of rules of general rather than particular applicability. The line is a relative one and impossible to defime im the abstract. A rule establishing certain safety standards for uranium mines is a rule of general applicability even though it may affect only a few mines. A rule requiring American Telephone \& Telegraph Co. to provide certain service in the future is a rule of particular applicability.

2. 5 U.S.C. $\$ 553$ (1970) [heremafter referred to as section 553]. This corresponds to Administrative Procedure Act of 1946, $\S 4$, ch. 324, $\$ 4,60$ Stat. 237. 
agency hearing" may be promulgated only by following the entirely different procedures specified in sections 556 and 557 of Title 5 (sections 7 and 8 of the $\mathrm{APA}^{3}$ ): there must be a "hearing" for the taking of evidence before the agency or a hearing examiner and the parties may conduct such cross-examination "as may be required for a full and true disclosure of the facts;" the agency decision must be based on the whole record and be supported by substantial evidence. Rulemaking pursuant to sections $\mathbf{5 5 6}$ and 557 is often described as "formal" rulemaking, "rulemaking on a record," or "legislation by adjudication." The APA, however, does not impose the full panoply of adjudicatory procedures on such rulemaking. ${ }^{4}$

The distinction between formal and informal rulemaking procedures may be analogized in a crude way to the distinction between a hearing before a legislative body and a hearing before a court. This analogy suggests the basic differences between the two types of procedures-indeed the distinction is sometimes phrased in terms of a legislative-type hearing as contrasted with a trial-type hearing.

The Administrative Procedure Act is polar with respect to rulemaking procedures: it does not recognize any alternative or intermediate types of procedures between informal rulemaking on the one hand and formal rulemaking on the other (except for the discretionary use of an oral hearing in cormection with informal rulemaking). It has been widely assumed by academic writers that rulemaking on a record is fundamentally an undesirable procedure ${ }^{5}$ and section $\Pi^{6}$ of this study demonstrates that such procedures may indeed be timeconsuming, expensive, and unduly burdensome on administrative agencies. It has not been generally recognized, however, that Congress, during the last decade, has evinced serious misgivings about pure notice-and-comment rulemaking. As described in section $\mathrm{III}^{7}$ of this study, most statutes enacted during this period require some procedures in addition to pure notice-and-comment rulemaking; in some statutes, a serious attempt has been made to blend requirements of formal rulemaking with informal procedures, creating a halfway house, as it were, between the polar extremes of the Administrative Procedure Act. While many of these attempts have not been completely thought through,

3. 5 U.S.C. $\$ \$ 556-57$ (1970) [hereinafter referred to as sections 556 and 557].

4. For example, 5 U.S.C. \& 556(d) (1970) [section 7(c)] provides that in rulemaking "an agency may, when a party will not be prejudiced thereby, adopt procedures for the submission of all or part of the evidence in written form." Also, since rulemaking on a record is not subject to 5 U.S.C. $\$ 554$ (1970) [section $5(c)$ ], the decision of the hearing examiner may be omitted, and the separation of functions requirement (section 554(d) [section 5(c)]) is inapplicable.

5. See, e.g., $1 \mathrm{~K}$. Davis, Administrative Law Treatise, \& 6.02 (1958).

6. See pp. 1283-1313 infra.

7. See pp. 1315-30 infra. 
they suggest the need for reexamination of the basic premise of the rulemaking provisions of the Administrative Procedure Act. ${ }^{8}$

\section{II}

\section{The Mandatory Use of Trial-Type Proceedings IN}

\section{Rulemaking: AN Evaluation of Rulemaking on a Record}

This section examines the statutes in which Congress has imposed the formal requirement that rulemaking be conducted "on a record after opportunity for an agency hearing," and evaluates the actual experience with the use of trial-type procedures in rulemaking.

\section{A. Agencies Required to Conduct Rulemaking on a Record}

The Administrative Procedure Act assumes that a determmation whether rulemaking on a record is applicable must be made by examining the substantive statute granting the rulemaking authority. ${ }^{\circ} \mathrm{A}$ random examination of Federal statutes reveals that inost older statutes do not impose any procedural requirements for rulemaking, ${ }^{10}$ and thus, rulemaking on a record is the exceptional rather than the ordinary situation.

Some statutes impose, in haec verba, a requirement that rulemaking be conducted "on the record."11 Equally unambiguous are statutes that do not use the inagic phrase "on the record" but specify in some detail that there is to be a formal evidentiary hearing and that the decision is to be based on substantial evidence in the record of such hearing. ${ }^{12}$

8. See pp. 1332-36 infra for recommended rules for rulemaking that adopt some of these middle-ground procedures.

9. See text accompanying notes 1-4 supra.

10. Grants of general authority to make interpretative rules or rules or regulations "necessary for the effective enforcement of the Act" almost invariably are free of procedural restriction. Also, agencies having a high degree of legislative confidence, such as the Internal Revenue Service and the Securities and Exchange Coinmission, possess broad grants of unrestricted rulemaking authority.

11. An example is section 10(b) of the Walsh-Healy Act, 41 U.S.C. \& 43a(b) (1970), as amended in 1952: "All wage determinations under section 35(b) of this title shall be made on the record after opportunity for a hearing." Similar language appears in the Drug Abuse Prevention and Control Act of 1970, 21 U.S.C. $\$ 811$ (a).

12. An example is section 701(e) of the Federal Food, Drug and Cosmetic Act, 21 U.S.C. \$371(e)(3) (1970):

As soon as practicable after such request for a public hearing, the Secretary, after due notice, shall hold such a public hearing for the purpose of receiving evidence relevant and material to the issues raised by such objections. At the hearing, any interested person may be heard in person or by representative ... [T] he Secretary shall by order act upon such objections and make such order public. Such order shall be based only on substantial evidence of record at such hearing and shall set forth, as part of the order, detailed findings of fact on which the order is based. 
The following table lists the agencies that administer statutes clearly requiring rulemaking to be conducted on a record, and describes the approximate number of formal hearings held pursuant to such statutes during the previous five years. ${ }^{13}$ The latter statistic gives a rough indication of the viability of the grant of rulemaking authority, though several of the figures require special explanation.

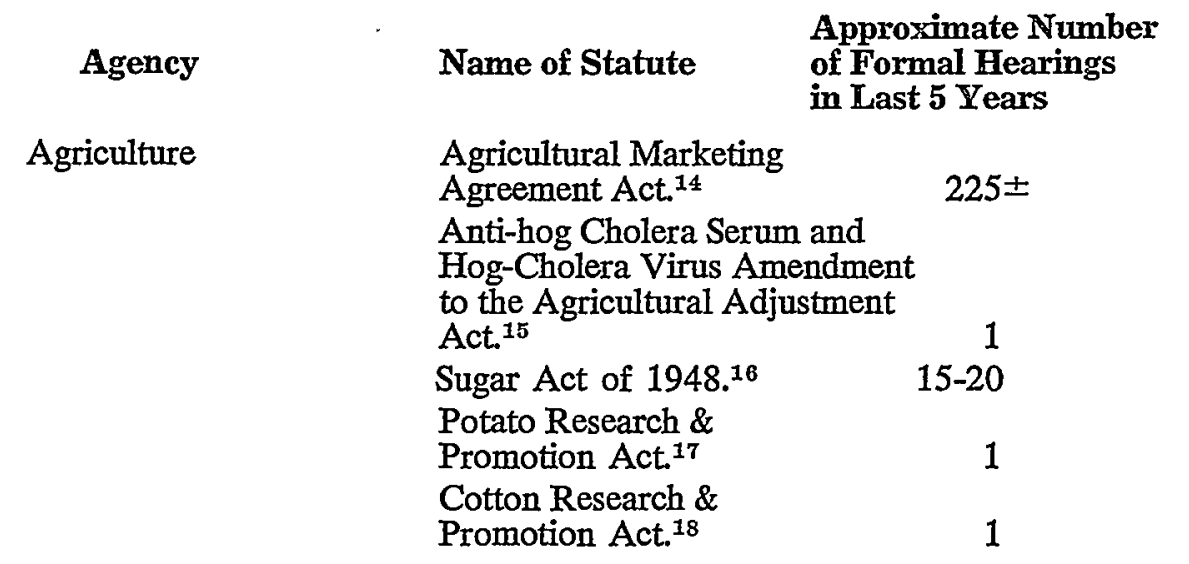

[Hereinafter, this section will be referred to as section 701(e).] Several statutes, such as the Fair Packaging and Labeling Act [15 U.S.C. \$ 1455 (1970)] expressly require the agency to follow the procedures set forth im section 701(e) in promulgating regulations. The force of precedent in imposing these additional procedural requiremeuts is thus manifest.

Several statutes administered by the Secretary of Agriculture also require rulemaking on a record, though the language used varies. The Agricultural Marketing Agreement Act of 1937 simply provides that the Secretary shall issue a marketing order if, after giving an opportunity for a hearing, "he finds, and sets forth in such order, upon the evidence introduced at such hearing" that the order will tend to effectuate the declared policy of the chapter. 7 U.S.C. $\$ \S 608 c(3),(4)(1970)$. Other statutes dealing with research relating to, and promotion of, cotton and potatoes track this language. Cotton Research and Promotion Act, id. \$§ 2103-04; Potato Research and Promotion Act, id. $\S \S 2614-15$. The Sugar Act of 1948 uses a different fonnulation. Hearings on all allocations of quotas to specific marketers or importers may be made only after "such hearing and upon such notice as [the Secretary] may by regulations prescribe." Id. $\$ 1115$ (a). A direct appeal is provided to the Court of Appeals for the District of Columbia Circuit, however. After the appeal is filed, the Secretary must "file with the court the record upon which the decision complained of was entered, as provided in section 2112 of Title 28," and "review by the court shall be limited to questions of law and ... findings of fact by the Secretary, if supported by substantial evidence, shall be conclusive unless it shall clearly appear that the findings of the Secretary are arbitrary or capricious. . . ."Id. $\$ \$ 1115(\mathrm{c})$, (e). Regulations issued by the Secretary under this sounewhat ambiguous section provide for a formal hearing.

13. This table is based on a brief questionnaire distributed by the Administrative Conference to member agencies inquiring whether any of their rulemaking authority was subject to an on-the-record requirement.
14. 7 U.S.C. $\$ \S 601,608 \mathrm{c}(3),(4)(1970)$.
15. Id. $\S \S 851-53$.
16. Id. $\S \S 1100,1115$.
17. Id. $\$ \S 2611,2614-15$.
18. Id. $\S \S 2101,2103-04$. 
Federal Trade
Commission
Justice

Justice \& Food \& Drug Administration Labor

Interior

Health, Education \& Welfare - Food and Drug Admimistration
Fair Packaging and

Labeling Act. ${ }^{10}$

Comprenhensive Drug Abuse

Prevention and Control Act of $1970 .^{20}$

Drug Abuse Control Act of 1965. ${ }^{21}$

Walsh-Healey Act.22

Fair Labor Standards Act. ${ }^{23}$

Metal and Non-Metallic Mine

Safety Act of $1966 .{ }^{24}$

Federal Food, Drug and

Cosmetic Act and related

Statutes. ${ }^{25}$

Fair Packaging and

Labeling Act. ${ }^{28}$

Federal Hazardous Substances

Act. ${ }^{27}$

Child Protection and Toy

Safety Act of 1969.*28

Poison Prevention Packaging

Act of 1970.*29

* These statutes give the FDA an option to proceed either under APA section 553 or under the requirements of rulemaking on a record.

19. 15 U.S.C. $\$ \S 1451,1455(\mathrm{a}),(\mathrm{b})$ (1970).

20. 21 U.S.C. $\$ \S 801,811$ (1970).

21. Pub. I. 89-74, § 3(a), 79 Stat. 227. Repealed by Comprehensive Drug Abuse Prevention and Control Act of 1970, Pub. L. 91-513, § 701(a), 84 Stat. 1236.

22. 41 U.S.C. $\$ 43 \mathrm{a}(\mathrm{b})(1970)$.

23. 29 U.S.C. $\$ \S 205-06(1970)$. Hearings are conducted under this statute by special industry committees to establish minimum wage rates for workers in Puerto Rico, the Virgin Islands and American Samoa. Each committee consists of an equal number of representatives of management, labor, and the public. 29 U.S.C. § 205(b) (1970). Hearings are conducted by the Committees themselves and the Secretary does not have authority to revise such determinations. Id. $\S 208$ (d). In effect, this is compulsory arbitration or mediation rather than rulemaking. The impact of the formal evidentiary hearing and the requirement that findings be based on substantial evidence of record is probably to limit the range within which the wage deternination may be made, though there has been virtually no judicial review of such deterninations. Apparently the only recent instances of such review are Bonita, Inc. v. Wirtz, 369 F.2d 208 (D.C. Cir. 1966), which decided a legal rather than a substantial evidence question, and Southland Manufacturing Corp. v. Secretary of Labor, 355 F.2d 836 (D.C. Cir. 1965), in which plaintiffs were unsuccessful in overturning the wage determination.

There are approximately 25 such committees (each covering several industries) which are required to review the determinations previously made at least every two years. The number of hearings is therefore not a particularly meaningful statistic.

In view of the peculiar function of these industry committees, they were not fully investigated and are not considered further.

24. 30 U.S.C. $\$ \$ 721,725(1970)$.

25. 21 U.S.C. $\$ 371$ (e) (1970).

26. 15 U.S.C $\$ \$ 1454,1455$ (a) (1970).

27. Id. $\S \S 1261-62$.

28. Id. $\S 1261(\mathrm{q}), 1262(\mathrm{e})(1)$.

29. Id. §§ 1471, 1474(a). 
In addition to the foregoing statutes clearly imposing an on-therecord requirement in rulemaking, some statutes contain provisions that may be subject to the construction that an on-the-record proceeding is conteinplated.

\section{1. "Full Hearing" Statutes.}

A large number of statutes grant rulemaking authority subject to a generalized requirement that the agency first hold a "hearing" or a "full hearing" or that the agency act only "after opportunity for hearing." Examples of such statutes are the common carrier sections of the Communications Act of $1934,{ }^{30}$ the Interstate Commerce Act of $1887^{31}$ and the Atomic Energy Act of 1954. ${ }^{32}$ As an abstract matter, there seems to be no reason why a section 553 proceeding should not satisfy the requirements of such statutes, and there are cases so holding. The most recent, and most authoritative statement to this effect appears in United States v. Allegheny-Ludlum Steel Corp where Justice Rehnquist stated:

We do not suggest that only the precise words "on the record" in the applicable statute will suffice to make $\S 556$ and 557 applicable to rulemaking proceedings, but we do hold that the language of the Escli Car Service Rules Act is insufficient to invoke these sections..$^{33}$

The one major exception involves the prescription of future rates-a particularized decision which commentators and courts generally agree must be conducted "on the record."

Matters, however, have a way of becoming encrusted with tradition. The ICC traditionally granted formal evidentiary hearings in proceedings involving the promulgation of rules of general applicabil-

30. 47 U.S.C. §§ 201-23 (1970).

31. 49 U.S.C. $\$ 1(14)(1970)$.

32. 42 U.S.C. $\$ 2239$ (a) (1970).

33. 90 S. Ct. 1941, 1950 (1972). The Attorney General's Manual states that "[t]here is persuasive legislative history to the effect that the Congress did not intend sections 7 and 8 [5 U.S.C. $\S \S 556-57(1970)$ ] to apply to rulennaking when the substantive statute inerely required a hearing." U.S. DEP'T OF JUSTICE, ATTORNEY GENeral's Manual on the Aoministrative Procedure Act 34 (1947. ) The Manual then describes the legislative history supporting this statement.

34. See Long Island R.R. v. United States, 318 F.Supp. 490 (E.D.N.Y. 1970). The Attorney General's Manual agrees, though it points out that in many instances the need for such a proceeding may be inferable from statutes defining judicial review. U.S. Dep't of Justice, ATtorney General's Manual on the AdmmisTrative Procedure ACr 33 (1947). However, the Federal Power Commission has attempted to regulate natural gas prices by informal rulenuaking under section 553 for the Appalachian and Illinois Basin and Rocky Mountain producing areas, and has argued that such a proceeding may comply with the "full hearing" requirennent of the Natural Gas Act, 15 U.S.C. $\$ 717$ (1970). See 35 Fed. Reg. 16077 (1970); 36 Fed. Reg. 13585 (1971). See also F.P.C. v. Texaco, Inc. 377 U.S. 33 (1964). 
ity (for example, safety standards), ${ }^{35}$ though its current practices vary. Apparently, the early practice of granting evidentiary hearings in promulgating rules of general applicability developed because the great bulk of ICC regulatory activity consisted of adjudication or particularized ratemaking, and the agency did not differentiate the general rulemaking proceedings from the balance of the agency business. As a result it has been held that the phrase "hearing" or "full hearing" within the context of the ICC implies a proceeding on the record. ${ }^{30}$ With the development of modified procedures, however, oral hearings in such proceedings became infrequent, and were limited to situations when material issues of fact are in dispute. ${ }^{37}$

\section{Statutes Requiring Determination of Prior Fact as a Condition for Promulgating Future Rules.}

Section 17 of the Shipping Act of $1916^{38}$ provides that carriers shall establish reasonable rules for the receiving, handling and storing of property entrusted to them for shipment. It also requires that the Federal Maritime Commission make a "finding" that certain regulations or practices are "unjust or unreasonable";,30 this finding arguably requires some sort of evidentiary learing as a condition for issuing rules.

35. When the Federal Railroad Administration of the Department of Transportation assumed the administration of the railroad safety statutes in 1967, it specifically declined to conduct proceedings under these acts on a rulemaking-on-a-record basis, claiming that a section 553 procedure met the statutory requirement. 33 Fed. Reg. 14327 (1968). This position was not tested in court and is now moot with the enactment of the Federal Railroad Safety Act of 1970 [45 U.S.C. $\$ 421$, et seq.] which permits section 553 rulemaking plus an opportunity for "oral presentations." $I d$. $\S 431$ (b).

36. Section 1(14)(a) of the Interstate Commerce Act [49 U.S.C. $\$ 14$ (a) (1970)] authorizes the ICC "after hearing" to establish the "compensation to be paid for the use of any [railroad] car not owned" by the carrier. In 1966, faced with a serious box car shortage, the ICC was authorized by Congress to establish compensation, taking into account the need to maintain and acquire an adequate car supply. Acting under Congressional pressure, the ICC promulgated general incentive rates on the basis of a study of freight car usage without a formal evidentiary hearing. No. 252 - Incentive Per Diem Charges, 337 I.C.C. 217 (1970). On review, Judge Friendly concluded that the establishment of nationwide imcentive rates under section 1(14) (a) must be "on the record" but that reliance solely on written evidence did not invalidate the rates because no party was prejudiced. Long Island R.R. v. United States, 318 F. Supp. 490 (E.D.N.Y. 1970). Another three-judge court assumed that section 1(14)(a) required an evidentiary hearing, and set aside the ICC order. Florida East Coast Ry. v. United States, 322 F. Supp. 725 (M.D. Fla. 1971).

37. These proceedings include two commercial zone determinations (discussed below in connection with the Department of Agriculture experience, see text accoinpanying notes 96-100 infra) and a proceeding instituted by Ralph Nader to ban smoking on interstate buses. 114 M.C.C. 256 (1971).

38. 46 U.S.C. $\$ 816(1970)$.

39. Id. 
The FMC, motivated at least partially by the statutory language, has conducted two proceedings under this section during the survey period. In each case it conducted a complete on-the-record proceeding, including a formal evidentiary hearing and an initial decision by the hearing examiner.

\section{B. Agency Experience With Rulemaking on a Record Requirements}

In this section primary emphasis is placed on the Food \& Drug Administration and the Department of Agriculture, the two agencies having the greatest experience with rulemaking on a record.

\section{The Food and Drug Administration (FDA $)^{40}$}

Section 701(e) of the Federal Food, Drug and Cosmetic Act ${ }^{41}$ was one of the first statutes to require rulemaking on a record. ${ }^{42}$ It is applicable to at least thirteen different grants of rulemaking authority, but only the following have given rise to formal hearings during the previous decade: establishment of food standards; ${ }^{43}$ labeling of foods

40. The summary that follows is partially based on an extensive study of FDA rulemaking proceedings recently completed by the author. R. W. HAMITON, RULEMaking on a Record by tHe FoOd aND DRUg Administration, Sept. 1971 [hereinafter cited as FDA REPORT.] Copies of this report may be obtained from the Administrative Conference of the United States. In December 1971 the Administrative Conference adopted Recommendation 29, addressed to the Food and Drug Administration, which was designed to improve the agency's performance of its rulemaking functions given its current statutory mandate. The present Article evaluates the desirability of the statutory mandate itself.

A modified version of my FDA report appears as Hamilton, Rulemaking on Record by the Food and Drug Administration, to be published in the Texas Law Review, August 1972.

41. 21 U.S.C. $\$ 371(\mathrm{e})(1970)$.

42. Four statutes dating from the late 1930's were apparently the first statutes to require rulemaking on a record. These statutes are: The Federal Food, Drug and Cosmetic Act (1938) 21 U.S.C. $\$ \S 301$ et seq. (1970), the Agricultural Marketing Agreement Act (1937), 7 U.S.C. $\$ \S 601$ et seq. (1970), the Bitummous Coal Act (1937), ch. 127, 50 Stat. 72, and the Fair Labor Standards Act (1938), 29 U.S.C. $\$ 201$ et seq. (1970). See FDA REPORT supra note 40, at 11-13 for a brief summary of the legislative history of section 701(e).

43. These hearings were held pursuant to section 401 of the Food, Drug and Cosmetic Act, 21 U.S.C. $\$ 341$ (1970). This section authorizes regulations estabhishing standards of identity, quality, or fill of container. Of the sixteen formal rulemaking hearings held by the FDA durimg the last decade, eleven imvolved food standards of identity. See text following note 67 infra. (These figures cover a ten year period, and thus differ from those set forth in the preceding table, which covers a five year period.) A twelfth proceeding, involving diluted orange juice drimks, is awaiting a formal hearing. See 37 Fed. Reg. 5224 (1972). Still another proceeding, involving "enriched macarom products with improved protem quahty," is controversial and may lead to another formal hearing. See 36 Fed. Reg. 4061 (1971). 
for special dietary uses; ${ }^{44}$ listing of color additives; ${ }^{45}$ labeling of prescription drugs, ${ }^{46}$ classifying drugs as depressant or stimulant; ${ }^{47}$ and banning hazardous household substances. ${ }^{48}$

FDA also has substantial rulemaking authority that is not subject to section 701(e), or that is subject only to portions of that section. The broadest grant of unrestricted rulemaking authority is section 701 (a) ${ }^{49}$ which authorizes the agency to promulgate regulations "for the efficient enforcement" of the Act. ${ }^{50}$ Long thought to authorize merely interpretive regulations, section 701(a) is the principal device by which FDA has sought to implement regulatory policies while avoiding the procedural thicket of section 701(e). In Abbott Laboratories v. Gardner, ${ }^{51}$ Justice Harlan stated that section 701(a) regulations may have the force of law and thus are subject to immediate judicial review.

44. These hearings were held pursuant to section $403(\mathrm{j})$ of the Food, Drug and Cosmetic Act, 21 U.S.C. $\$ 343(\mathrm{j})$ (1970). The one rulemaking proceeding involving this section during the last decade, Foods for Special Dietary Uses [see notice of proposed rulemaking, 27 Fed. Reg. 5815 (1962) and compare order at 31 Fed. Reg. 8521 at 8524-25 (1966), affd, Pharmaceutical Mfrs. Ass'n v. Gardner, 381 F.2d 271 (D.C. Cir. 1967)], was the largest and most unwieldy rulemaking proceeding ever conducted by the FDA.

45. Section 706 of the Food, Drug and Cosmetic Act, 21 U.S.C. $\$ 376$ (1970). This section requires the Commissioner to maintain a list of color additives "suitable and safe for use" in food, drugs or cosmetics. One proceeding, involving the de-listing of certain coal tar colors, arose in the early 1960's.

46. Section 502(n) of the Food, Drug and Cosmetic Act, 21 U.S.C. $\$ 352(n)$ (1970). One formal proceeding arose under this section during the past decade. During the samc period there have been several amendments to regulations under section 502(n) which were the subject of extensive negotiations between FDA and the drug industry, but they did not give rise to a formal liearing.

47. Section 201(v) Federal Food, Drug \& Cosmetic Act of 1938; Drug Abuse Control Act of 1965, Pub. L. 89-74, § 3(a), 79 Stat. 227. (repealed by Comprehensive Drug Abuse, Prevention and Control Act of 1970, Pub. L. 91-513, § 701(a), 84 Stat. 1236).

Two proceedings arose under this section during the preceeding decade. However, rulemaking authority under this section was transfered to the Bureau of Narcotics and Dangerous Drugs (BNDD) of the Department of Justice on April 8, 1968. Reorganization Plan No. 1 of 1968, 33 Fed. Reg. 5611. The two proceedings were then completed by that bureau and are briefly described below in connection with the Department of Justice. See text accompanying notes 148-160 infra. The Comprehensive Drug Abuse Prevention and Control Act of 1970 [Pub. L. 91-513, 84 Stat. 1236 (codified in scattered sections of 18,21,26, 31, 40, 42 and 46 U.S.C.)] also contains a modified rulenaking-on-the-record requirement '(section 201(a)) which is discussed in section III.

48. Federal Hazardous Substances Act, 15 U.S.C. $\$ \S 1261$ et seq. (1970). One formal proceeding involving carbon tetrachloride has been completed under this section, and a second proceeding, involving fireworks, may result in a public hearing. See 37 Fed. Reg. 6868 (1972).

49. Federal Food, Drug and Cosmetic Act of 1938,21 'U.S.C. \& 371 (a) (1970).

50. Id.

51. 387 U.S. 136 (1967). 
Under section 701(e) FDA administers a multiphase rulemaking procedure that combines most of the attributes of informal as well as formal rulemaking, and must surely set some sort of record for the number of required procedural steps. In effect, the agency must first conduct a regular section 553 rulemaking proceeding, mcluding the publication of a notice of proposed rulemaking, the solicitation of comment, and the publication of an order setting forth the rule. ${ }^{52} \mathrm{~A}$ formal evidentiary hearing is thereafter held only if a person "who will be adversely affected by such order if placed in effect" files objections to the order, specifying with particularity the objectionable provisions, stating the grounds of his objection, and requesting a formal hearing. ${ }^{53}$ The filing of objections operates as a stay of the effectiveness of the part of the order to which objection is made. ${ }^{54}$

At the hearing, the proponent of the rule has the burden of supporting the stayed rule by substantial evidence of record. Sometimes regulations are requested by a manufacturer and opposed by other manufacturers. In those proceedings the agency participates in the hearing as a kind of observer or consumer advocate. When, however, as has often been the case, the agency proposes the rule on its own motion, it must supply affirmative evidence supporting its position and make its experts available for cross-examination.

The legislative history indicates that a full-fledged trial-type hearing was imtended, and the regulations fully carry out this intention..$^{55}$ The hearing is conducted by an APA hearing examiner. ${ }^{56}$ It "is directed to receiving factual evidence and expert opinion testimony related to the issues in the proceeding." "57 Witnesses are sworn and are available for cross-examination by any participant. ${ }^{58}$ Objections to the admission or rejection of evidence, or to limitations of the scope of examination are entertained. ${ }^{59}$ A stenographic record of the hearing is made, and the record may be corrected at the conclusion of

52. 21 U.S.C. $371(\mathrm{e})(1)(1970), 21$ C.F.R. $\S \S 2.66(\mathrm{a})$, (b) (1972).

53. Id. $\S 371(\mathrm{e})(2), 21$ C.F.R. $\S 2.67(\mathrm{~b})(5)$.

54. Id. $\$ 371(\mathrm{c})(2), 21$ C.F.R. $\$ 2.67(\mathrm{e})$.

55. The House report of the bill (S. S) that ultimately became the Food, Drug and Cosmetic Act of 1938 states that:

while common law or jury trial rules of evidence need not be enforced at such a hearing, nevertheless it is essential to such a hearing that all evidence on which the administrative officer acts be disclosed at the hearing and that the right to controvert viva voce be accorded.

H.R. REP. No. 2139, 75th Cong., 3d Sess. (1938); reprinted in C. DunN, FederaI FOOD, DRUG AND COSMETTC ACT 824 (1938).

56. 21 C.F.R. \& 2.71 (1972).

57. Id. $\$ 7.79$.

58. Id $\S 2.81$.

59. Id. $\S 2.83$. 
the hearing. ${ }^{00}$ The transcript, exhibits and any written argument that may have been filed at or in connection with the hearing constitute "the exclusive record for decision."

After the hearing is completed and briefs are submitted, the presiding officer prepares a report and certifies the record together with his report to the Commissioner. ${ }^{62}$ A tentative order is then published in the Federal Register under the name of the Commissioner. This is an institutional decision which may or may not agree with the hearing examiner's report. After exceptions by any party of record, a final decision and order is published in the name of the Commissioner. ${ }^{03}$ The final order includes detailed findings of fact and conclusions upon which the order is based. Such findings are typically lengthy and replete with numerous citations to the transcript and documentary exhibits. This final order, which by statute must "be based only on substantial evidence of record" at the hearing, ${ }^{64}$ is subject to judicial review in the court of appeals for the circuit where the person seeking judicial review resides or has his principal place of business. ${ }^{05}$ Findings of fact, if supported by substantial evidence, are conclusive, but the court has jurisdiction to set the order aside in whole or in part, temporarily or perinanently, and may order the Secretary to issue, amend or repeal any regulation in accordance with its decision. ${ }^{06}$ Further, the court may remand the proceeding to the agency for the taking of additional evidence upon request of the petitioner and a showing that such additional evidence is material and that there were reasonable grounds for not adducing the evidence at the hearing. ${ }^{07}$

This procedure is clearly very burdensome for the agency. It requires at least four different evaluations of the rulemaking proposal by FDA-a proposed rule, a final order promulgating the rule, a tentative decision after the formal hearing, and a final decision after exceptions. In addition, the hearing examiner prepares a report which is only advisory. The greatest burden, however, is the preparation and holding of the formal evidentiary hearing, which is in effect a trial of a major lawsuit.

60. Id. $\$ \S 2.90(\mathrm{a}), 2.93$.

61. Id. $\S 2.94$.

62. The report consists of suggested findings of fact and conclusions of lawin other words, a tentative initial decision. It is not released to the public, however, until after the tentative order is prepared by the Commissioner.

63. 21 C.F.R. $\S 2.98$ (1972).

64. Federal Food, Drug and Cosinetic Act $\S 701(e)(3), 21$ U.S.C. 371(e)(3) (1970).

65. Id. \&371(f)(1).

66. Id. \& 371(f)(3).

67. Id. $\$ 371(\mathrm{f})(2)$. 
Most section 701(e) proceedings do not run the full gamut described above. The FDA conducts literally hundreds of rulemaking proceedings under section 701(e), each of which terminates after the proposal-comment-order stage. In only sixteen instances during the 1960's did the Commissioner find it necessary to hold a formal evidentiary hearing. Two factors largely explain this phenomenon. The formal hearing is so time-consuming and expensive that there is a strong impetus for both the agency and the affected industry to compromise their differences and thus avoid the hearing. ${ }^{68}$ Further, the FDA has evolved a denial-of-hearing practice based on an extremely strict notion of what objections are legally sufficient to trigger a formal hearing. ${ }^{69}$

The sixteen formal hearings that were held during the last decade vary fronı unnecessarily drawn out proceedings to virtual disasters. In not one instance did the agency complete a rulemaking proceeding involving a hearing in less than two years, and in two instances more than ten years elapsed between the first proposal and the fimal order. The average time lapse was roughly four years. ${ }^{70}$ The hearings themselves tended to be drawn out, repetitious and unproductive. The Foods for Special Dietary Uses ${ }^{71}$ hearing consumed over 200 days of testimony and amassed a transcript of more than 32,000 pages. Most of the learing was devoted to cross-examination of expert government witnesses. ${ }^{72}$ Another proceeding involving the standard of identity

68. Of course, in many situations a person affected by an order may be opposed to it, yet not be so adversely affected as to demand a formal hearing. Also, many FDA rulemaking proposals are not controversial at all and these also end at the proposal - comment - order stage of the proceeding.

69. Agency personnel often refer to these denials as "summary judgments," though in some instances unresolved questions of fact are clearly present. For economic regulation such as food standards, demals of hearings have generally been limited to situations where it seemed unlikely that judicial review of the order denying the hearing would be sought. Some of these denials cannot possibly be justified, however, and while the end result inay be beneficial (the proceeding terminating at the conclusion of the notice-comment-order stage), the agency appears to be engaging in essentially lawless behavior.

This development is the progeny of Dyestuffs and Chemicals, Inc. v. Fleming, 271 F.2d 281 (8th Cir. 1959). For a discussion of this case see FDA REPorT, supra note 40.

70. The numerous steps in the section $701(\mathrm{e})$ process and tbe time consumed in preparing for and conducting a formal evidentiary hearing do not explain all these delays. Bureaucratic slippage, long delays to conduct studies and negotiate with industry, and the low priority of these proceedings within FDA were also contributing factors.

71. The hearing was held in connection with the order printed at 31 Fed. Reg. 8521, 8524-25 (1966).

72. Much of this cross-examination was cumulative or repetitious and difficult to justify on any basis. Further, inuch of the testimony involved opinions of experts on which a firm consensus would be impossible to reach. An expert witness is un- 
for peanut butter developed a transcript of over 7,700 pages, largely directed to the question whether the product peanut butter should consist of 90 percent peanuts or $871 / 2$ percent peanuts. ${ }^{73}$ Both of these transcripts are largely monuments to free speech.

A number of factors have contributed to the problems the FDA has encountered in formal proceedings. The FDA has had its greatest problems with hearings on proposals it initiated on its own motion. Since the proponent of proposed regulations has the burden of adducing substantial evidence to support them, the FDA is required in these proceedings to produce its own employees or expert witnesses to support its proposal. These witnesses have been subjected to cross-examimation which was often imtense, wide-ranging, and usually unproductive. Also, because of the burden of persuasion, the agency attorney at the hearing is inevitably cast as an advocate proving a case rather than as a disinterested representative of the public interest.

Furthermore, the early stages of the section 701(e) procedure tend to weed out the insignificant or less controversial issues; only the most bitterly controverted proceedings in which all opportunity for agreement and compromise has been exhausted go to hearing. Typically, the stakes are high and the disagreement with the agency proposal fundamental.

The food and drug industries are dominated by a sinall number of corporations; these einploy articulate and effective counsel to exploit procedural devices available to them. On more than one occasion the industry evidently decided it is cheaper to pay a lawyer for cross-examining at a hearing than it is to comply with a proposed rule it bitterly opposed. Moreover, many FDA hearings involve inultiple parties, each of whom is affected by the proposed regulation in essentially different ways. Numerous parties therefore feel impelled to participate actively in the hearing, leading to repetition and delay.

The issues involved in formal hearings often involve questions of policy as much as questions of fact. Professor Davis has cominented that a trial-type hearing is imappropriate to resolve the issue whether "golden" should be a synonyin for "yellow" in labeling canned corn, or whether pear halves should have a minimuin weight of $4 / 5$ ounces or $3 / 5$ ounces. $^{74}$ There may be factual issues underlying such broad

likely to be shaken by cross-examination which requires comment on other statements by the same or different expert witnesses.

73. Tentative findings of fact and conclusions of law were published more than 18 months after the hearing ended. 32 Fed. Reg. 17482 (1967). The final order was issued 7 months later. 33 Fed. Reg. 10506 (1968), aff'd Com. Prod. Co. v. FDA, 427 F.2d 511 (3d Cir. 1970), cert. denied sub. nom., Derby Foods, Inc. v. FDA, 400 U.S. 957 (1970).

74. $1 \mathrm{~K}$. Davis, Administrative Law Treatise $§ 6.06$ (1958). 
policy questions - for example, what is the industry practice with regard to the size of pear halves, or what is the consumer understanding on the same question-but the FDA typically has not held hearings on the underlying factual questions. Instead it has phrased the issue in terms of the statutory language itself. The result has been a rambling, unfocused hearing.

Even when there are obvious factual issues, they are often so broad as to be inappropriate for a trial-type hearing. An outstanding example of such an issue was the basic one underlying much of the Foods for Special Dietary Uses proceeding: Is the diet of the average American reasonably adequate in vitamins and minerals? The views of expert nutritionists may conflict on such a question, and the testing by cross-examination of differing views is likely to be both time-consuming and unproductive. Similarly, issues may involve scientific questions in which the basic problem is lack of persuasive proof one way or the other. A trial-type hearing before a non-expert hearing examiner is not the best way to resolve such questions. Of course, not all issues in FDA hearings are so broad, and in some proceedings the use of formal hearing procedures has in fact been productive. For example, in the DSS in Cocoa proceeding, ${ }^{75}$ an industry-mstituted proceeding involving the use of a new dispersant in cocoa, the hearing produced considerable information not previously available to the agency as to the techniques used by manufacturers to improve the dispersant characteristics of cocoa. Such instances, however, are the exception rather than the rule.

The FDA's problems are coinpounded because it has not adopted procedural devices used by other agencies to make manageable large multi-party administrative hearings. While such devices probably would not be cure-alls, they would have simplified the agency's problems. To this extent at least, FDA's problems are of its own making. ${ }^{76}$

Fornal evidentiary hearings as conducted by the FDA have very substantial disadvantages and have had serious adverse consequences on the agency's ability to fulfill its statutory mandates. Most seriously, the procedural requirements have warped the entire substantive regulatory position of the agency. The formal hearings have been so painful in the past that the agency now takes the position that it will go to almost any length to avoid them. Substantive policy decisions are

75. See 36 Fed. Reg. 23150 (1971) for the final order in this proceeding.

76. Following my FDA report [see FDA REPORT, supra note 40] the Administrative Conference adopted Recommendation 29, designed to improve FDA's regulatory processes under its present statutory mandate. The agency has taken the first steps towards implementing this Recommendation [see 37 Fed. Reg. 6107 (1972)], and it may be hoped that the balance of the recoinmendations will be adopted as well. 
based in part on the likelihood that promulgation of a regulation may lead to a formal hearing. ${ }^{77}$

Further, as noted previously, the agency bargains with the affected mdustry in order to reach a consensus that avoids a hearing. The right to a hearing becomes the principal bargaining lever by the imdustry, to be given up only in exchange for substantive modifications of proposed rules. It is likely, but undocumentable, that these substantive concessions have to some extent compromised the public interest, or at least have watered down the FDA's regulatory goals.

A coinparison of the FDA's administration of the Federal Hazardous Substances Act, ${ }^{78}$ which requires the agency to follow section 701(e), and the more recent Child Protection \& Toy Safety Act, ${ }^{70}$ which permits informal rulemaking, also reveals the harmful effect of section 701(e). FDA has attempted to ban only three or four substances under the Hazardous Substances Act, while it has removed, or caused to be modified, hundreds of potentially dangerous toys.

Formal evidentiary hearings have also tended to cause ahenation between the scientific community and the FDA. ${ }^{80}$ In part this has been the result of subjecting volunteer, expert witnesses to a grueling cross-exaunination; in part it arises from the common-sense notion that a formal evidentiary hearing is not necessarily the best way to determine scientific principles.

In contrast to these undeniably serious disadvantages, it is difficult to see how these hearings serve any substantial purpose. In evaluating the desirability of retaining formal hearings under section 701 (e), the advantages must of course be weighed against the disadvantages; on this balancing, the disadvantages seem to outweigh the slight advantages by far.

77. For example, the FDA for years has been faced with a serious regulatory problem with respect to products which appear to be orange juice but consist mainly of water, sometimes combined with orange pulp or juice. The FDA recently published three proposals for food standards for these products. These regulatory proposals are highly controversial within the industries involved and clearly fall within section 701 (e). In order to avoid a hearing, the agency considered a proposal to require only labeling of orange juice content without establishing any food standard. The agency believed the labeling proposal could be adopted in a simple notice-and-comment rulemaking proceeding under section 701(a). Perhaps the substantive policy decision to move towards percentage labeling and away from a food standard was sound; perhaps not. It is clear, lowever, that the decision was being considered not solely on the basis of substantive considerations but partly because of a desire to avoid the procedural requirements of section $701(\mathrm{e})$.

78. 15 U.S.C. $\$ \S 1261$ et seq. (1970).

79. Id. $\$ \$ 1261,1262,1274$ (1970).

80. See, e.g., Higsted, Food Standards, 24 Food, Drug Cosm. L.J. 384, 385 (1969), published while the Food for Special Dietary Uses hearing was underway. 
There are three possible justifications for formal evidentiary hearings: (a) to develop information so that the agency may make a reasonable decision, (b) to create a record for judicial review of the agency's determination, and (c) to give persons affected by the proposed rules an opportunity to question the agency's factual premises. The FDA formal hearing does not effectively serve any of these purposes.

a. Development of factual information. Most evidentiary hearings are intended to develop accurate information so that the agency may make a sensible decision. In this respect, an evidentiary hearing may either be a substitute for inviting comment on a proposal, or it may be a supplement to comments when irreconcilable factual disputes appear from such comments.

In rulemaking proceedings by the FDA, it is generally conceded that most facts underlying the proposed regulation and most facts on which opponents rely are obtained by the agency either informally before the notice is published, in the notice-comment-order stage of the section 701(e) procedure, or in the objections filed after the order; the formal hearing largely covers already plowed ground. The original justification for the formal hearing may partly have been based on the assumption that it would develop factual information, but under the current procedure ${ }^{81}$ factual information is developed primarily during the early stages of the proceeding. This is particularly clear where the FDA has the burden of supporting the proposed rules by substantial evidence. The formal hearing then tends to be viewed by the agency merely as a device for creating a record supporting administrative decisions previously reached. The FDA attorney at the hearing need not be particularly concerned with persuading the agency as to the correctness of the views he is espousing. He is reasonably confident that where a contradiction in views on a broad policy question occurs, the agency decision will cite the views of the witnesses he calls rather than the contradictory testimony of witnesses called by other participants, and that such testimony will probably be sufficient to uphold the finding on judicial review. ${ }^{82}$

b. Judicial review. The most obvious possible justification of the formal hearing is that it provides a record for judicial review, which

81. As originally enacted, section 701 (e) required a formal evidentiary hearing in every proceeding. In 1956 it was amended to require a hearing only when objectiou to the proposed regulations is made. Federal Food, Drug and Cosmetic Act $\$ 701(\mathrm{e})$, ch. 675 , § 701 (e), 52 Stat. 1040 (1938), as amended 21 U.S.C. 371(e) (1970).

82. Of course, the findings must be supported by substantial evidence of record, taking the record as a whole, and industry participants have sometimes complained that the FDA practice of relying on government witnesses and ignoring contradictory testiniony of industry experts fails to neet the Universal Camera standard. Universal Camera Corp. v. NLRB, 340 U.S. 474 (1950). 
permits a court to determine whether there is rational support for the agency's factual assumptions. It is of course true that rulemaking on a record does provide a record similar to a record in adjudication and permits judicial review of the factual findings on the basis of a substantial evidence test. Because of the setting of the hearing and the types of issues involved, however, it is unlikely that this review provides a very meaningful check against agency action.

Furthermore, since the controverted issues in most FDA rulemaking procedures involve broad economic or policy questions rather than particularized factual issues, conflicting or contradictory expert opinions and views are inevitable, and a court is unlikely to overturn the FDA's conclusion. Also, on the basis of certain core facts not seriously in dispute, the agency may usually justify several different policy decisions, any one of which the court will uphold. ${ }^{83}$ Under these circumstances it is not surprising that FDA's track record on appeal is very good.

c. Correction of agency errors. A soinewhat different justification for the evidentiary hearing has been put forth by Mr. H. Thomas Austern, a leading meinber of the FDA bar. He suggests that section 701 (e) proceeds on the theory that "he who regulates ought to appear publicly if there is a challenge, and put on the table, subject to crossexamination, the facts on which he grounds his proposal." 84 While it might be thought that this, too, should ultimately lead to more meaningful judicial review, Mr. Austern immediately denies that such review is meaningful: "Judicial review is largely a phantom. In my own experience there are few courts that will second-guess the Food and Drug Administration, which has the reputation of protecting the consumer, the aged, the infirm, the ignorant, and the nursing infant." The advantage of the proceeding is to give the concerned industry an opportunity, by cross-examination, to point out to the agency that the factual assumptions on which the agency is proceeding are erroneous. He concludes:

[T]he Government's role is often too narrowly conceived. FDA counsel ought not merely be an advocate for the Commissioner's final order. He has an obligation constantly to evaluate the progression of the evidence and to consider whether contested issues

83. In the Peanut Butter proceeding [see text following note 72 supra], for example, once the agency shows consumer confusion and a product varying in content over a period of time, it is faced with a policy question, not a factual question. On the record made by the agency, it is unlikely that a court would overturn an 87 percent standard, a 90 percent standard, or even a 95 percent standard.

84. H. Austern, Food Standards: The Balance Between Certainty and Innovation, 24 Food Drug Cosm. I.J. 440, 451 (1969).

85. Id. 
can be negotiated when it appears that the position originally espoused cannot be supported by significant evidence outside the parochial confines of the agency, or that it is not necessary for consumer protection. ${ }^{86}$

In other words, the basic purpose of the evidentiary hearing is to give industry an opportunity to persuade the agency that its factual assumtions are wrong, or at least that factual issues can be negotiated. In this view, the agency should use the formal hearing not to create a formal record which will support by "substantial evidence" certain conclusions previously arrived at, but instead to determine as an original trier of facts, without preconceptions, which position is supported by a preponderance of the evidence. Also, under this view what government witnesses say on direct examination is not as significant as what they say on cross and what industry witnesses say on direct. The Foods for Special Dietary Uses hearing is often cited as an illustration of the need for this kind of check on agency factual assumptions.

There are problems with this justification for formal evidentiary hearings, though the argument cannot be completely rejected. In the first place, there seems to be no reason why fundamental agency misconceptions cannot be corrected at the proposal-comment-order stage of the proceeding, except perhaps on the assumption that the FDA is singularly obtuse to written argument. Secondly, noost agencies avoid factual misconceptions in rulenlaking without a formal hearing; there seems to be no reason why the FDA cannot do so also.

It is probably true that the over-200-day hearing in the Foods for Special Dietary Uses proceeding has had some effect on the ultimate position the agency will take on the matters discussed during it. However, the cost of this proceeding was so staggerimg that one cannot help but conclude that it was not worth it, and that there must be a better way of correcting agency error.

\section{The Department of Agriculture}

The contrast between the procedures followed by the FDA and those used by the Department of Agriculture is striking. The Department administers several statutes which require rulemaking on a record. The most important of these statutes is the Agricultural Marketing Agreement Act of 1937, as amended. ${ }^{87}$ The other statutes involve rulemaking authority quite similar to that granted by the Agricultural Marketing Agreement Act and are not separately discussed. ${ }^{88}$

86. Id. at 453 .

87. 7 U.S.C. $\& 601$ et seq (1970).

88. The Potato Research and Promotion Act, 7 U.S.C. $\$ \$ 2611$ et seq. (1970), the Cotton Research and Promotion Act, 7 U.S.C. $\S \S 2101$ et seq. (1970), the Sugar 
The Agricultural Marketing Agreement Act ${ }^{80}$ authorizes the Secretary to establish, by a system of marketing orders and agreements, what is in effect a detailed regulatory program for maintaining prices paid to farmers. The program affects prices either directly or by tinkering with supply. ${ }^{00}$ The orders and agreements fall into two groups: those relating to milk, and those relating to perishable agricultural products-most fruits, vegetables, tree nuts, peanuts, and hops. Regulation in each of these two groups is on an entirely different basis.

The economics of the milk industry is distinguished first by a two-price structure that permits different returns for the same product depending on its ultimate use and second by the cyclical character of production-an adequate herd in the low-yield winter months produces a glut of milk each spring. As a consequence, the regulation of fluid milk is extremely complex..$^{91}$ The orders fix the minimum price handlers (dairies) pay to producers (farmers) supplying milk for sale in a "marketing area" (usually an urban area) through a system of pools that takes into account the various uses of milk..$^{22}$

Marketing orders for non-milk commodities are based on production areas rather than marketing areas as in milk. These orders attempt to improve prices to farmers by controlling supply directly; they operate on "the smallest practicable regional production area." Unlike milk orders, fruit or vegetable orders contain provisions permitting the issuance or modification, without notice or a formal hearing, of some regulations governing the liandling of the commodity. The justification for this summary procedure is that the need to alter supply restrictions on perishable agricultural commodities may arise sudden$1 y ;{ }^{94}$ in practice, however, most of the meaningful rulemaking decisions in the fruit and vegetable program are nnade summarily, and only the

Act of 1948, 7 U.S.C. $\$ \S 1100$ et seq. (1970), and the Anti-Hog-Cholera Serum and Hog-Cholera Virus Amendment to the Agricultural Adjustment Act, 7 U.S.C. $\$ \S 851$ et seq. (1970).

89. 7 U.S.C. $\$ \S 601$ et seq. (1970). 1972).

90. Id. § 602(4). See Rasmussen v. Hardin, No. 25,669 (9th Cir., Mar. 29,

91. For a discussion of the complexities of milk industry regulation see Zuber v. Allen, 396 U.S. 168, 172-73, 177-78 (1969).

92. At the present time there are outstanding some 60 -odd milk orders covering most of the urban areas of the country. Amendments to such orders are common, and each such amendment must be the subject of a formal hearing. 7 U.S.C. $\S 608$ (c) (17).

93. 7 U.S.C. $\& 608($ c)(11)(B). There are 40 -odd orders outstanding under this program, each established or amended pursuant to a formal hearing.

94. One recent amendment, for example, was issued without notice or hearing to relax supply restrictions "so as to provide access to a larger quantity of marketable grapefruit due to freeze damage encountered in the production area." 36 Fed. Reg. 8671 (1971). 
framework of the regulatory machinery is subject to the formal hearing requirement. From the standpoint of the agency, of course, these summary orders provide much needed flexibility. Persons adversely affected claim, however, that they should be entitled to greater procedural rights in these determinations. ${ }^{95}$

Administration of these programs is conducted by the Agricultural Marketing Service (AMS) ${ }^{96}$ of the Department of Agriculture. The procedure for promulgating a marketing order is entirely different from the procedure followed by the FDA. First of all, proposals for marketing orders are usually drafted by a group of producers or a cooperative. The AMS gives advice and guidance in the drafting of a proposed order to make sure that the order meets legal and departmental requirements, and that the order proposed appears to be one that the Department may reasonably accept.

After the proposed order is filed, AMS nnakes a preliminary investigation to determine whether the order "will tend to effectuate the declared policy of the act."97 If so, a notice of liearing is published in the Federal Register. The notice includes a copy of the proposed order and describes the persons affected and the purpose of the proposed hearing. ${ }^{98}$ The purpose, for example, may be "to receive evidence with respect to the economic and marketing conditions which relate to the proposed amendments hereinafter set forth."99 Personal notice of the hearing is given all interested handlers and producers known to AMS. Press releases are also given to newspapers in the affected area, and copies are sent to the governors of all affected states. ${ }^{100}$

95. In Walter Holm \& Co. v. Hardin, 449 F.2d 1009, (D.C. Cir. 1971), the Department attempted to issue a regulation under the Florida Tomato Marketing Order [7 C.F.R. $\$ 996$ (1972)] restricting the size of tomatoes that might be sold. A similar restriction was imposed on imported tomatoes. The Department conducted a section 553 rulemaking proceeding but declined to give an oral hearing. On review brought by importers of Mexicau tomatoes, the court held that in view of the issues presented, "basic considerations of fairness" and Congressional inteut required an opportunity to make an oral presentation to Departmental officials. 449 F.2d at 1016 . The hearing, however, could be of a legislative type.

96. Formerly the Consumer and Marketing Service, the name was changed in early 1972. 37 Fed. Reg. 6327,8059 (1972).

97. 7 C.F.R. $\$ 900.3$ (b) (1972). The agency recently rejected a contention that it had "engaged in improper discussion with proponeuts in the development of the proposals," saying that "the act and the rules of practice both contemplate and provide that the Department will inquire into the potential merits of a proposal for an order before a hearing is called." 37 Fed. Reg. 1366 (1972).

98. 7 C.F.R. \& 900.4 (1972).

99. A recent milk order amendıneut hearing at 35 Fed. Reg. 14324 (1970). Some statements of purpose are inuch more elaborate; see the proposed order governmg Lettuce Grown in California, Arizona, Colorado, New Mexico and Designated Parts of Texas, 36 Fed. Reg. 1266 (1971).

100. 7 C.F.R. $\$ 900.4$ (b) (i-iv). 
A formal evidentiary hearing is then held. This hearing is presided over by one of the six APA hearing examiners in the Department of Agriculture and usually is held at one or more places in the area affected by the order. The number of persons in attendance may be as many as 200 .

The AMS is represented at the hearing by one or more attorneys and one or more marketing specialists. These persons do not consider themselves to be advocates for or against the proposed order; they rarely ask questions, and then only to clarify the record. Indeed, the marketing specialists at the hearing usually will have primary responsibility for formulating the recommended and final decision ultimately issued, and the Agency has recently explicitly stated that its role in the hearings is to encourage development of a record containing the relevant facts, rather than to advocate a position. ${ }^{101}$ AMS personnel ordimarily do testify at the beginning of the hearing to put into the record relevant statistics independently collected by the Department and are subject to cross-examination to clarify the meaning of the statistics. A general presentation by the proponents of the order usually follows. The hearing is then broken into different problem areas, such as: the need for the order, the extent of interstate coinmerce affected, the definition of the proposed production or marketing area and the purpose, scope and ineaning of the proposed order, taken section by section. A witness presents testimony on only one problem area at a time and is cross-examined by anyone who wishes to ask questions about the subject. Witnesses are sworn, ${ }^{102}$ and direct testimony may be in narrative form or read from a prepared statement. All proponent witnesses testifying on the same problem area are first called. Thereafter, other persons desiring to testify on the problem area are called and also are subject to cross-exammation. After all testimony is taken on one problem area, the hearing then moves to the next area.

One important safety check on the process of cross-examination is that any witness may refuse to answer a question that he considers irrelevant, personal or repetitious. The only effect of such a refusal is possibly to cast doubt on the balance of his testinnony. There is no power to issue subpoenas in these proceedings or to compel responses.

In milk hearings, the principal economic groups are usually represented by counsel experienced in milk marketing order problems, though individual farners or dairy owners may appear without counsel. In commodity marketing order cases, many persons appear with-

101. 37 Fed. Reg. 1366 (1972).

102. 7 C.F.R. $\$ 900.8$ (d) (1) (1972). 
out counsel. The hearing examiner, and to a lesser extent the AMS attorney, attempt to assist lay witnesses and the cross-examiners. If a person asking a question begins to testify, the examiner may interrupt him and suggest that he wait, be sworn, and testify directly. If a person from the audience indicates that he thinks he may be adversely affected by the order, the hearing examiner may suggest he be sworn and testify concerning the nature of his business, the effect the order will have, and so forth. The hearing examiner may question these witnesses, who may then be cross-examined by other persons at the hearing.

The hearing examiner conducts the proceeding with the goal of building an orderly factual record. This goal was substantially achieved in the hearings examined for this study.

After the hearing is completed, written argument, briefs and proposed findings are submitted. ${ }^{103}$ The examiner certifies the accuracy of the transcript, ${ }^{104}$ but does not prepare an initial decision; rather, the recommended decision ${ }^{105}$ is an imstitutional one issued in the name of the Administrator of the AMS. It is prepared largely by the marketing specialist who attended the hearing, subject to review and direction by his superiors and to review by the General Counsel's office. The recommended decision, consisting of a narrative statement of facts setting forth the need for the order, describing the effect on interstate commerce, and so forth, is based solely on the record. It rules on each proposed finding and conclusion, and sets forth an appropriate proposed inarketing agreement or order. ${ }^{106}$

Exceptions may be taken to the recommended decision. ${ }^{107}$ The final decision, issued in the name of the Secretary of Agriculture, ${ }^{108}$ is prepared with the assistance of the AMS staff, including the inarketing specialist who had primary responsibility for formulating the order and the Department attorney who was present at the hearing. While there is no isolation within the staff, the Departmental regulations prohibit any discussion of the merits with persons outside the Department who are interested in the proceeding. ${ }^{109}$

Following the issuance of the fimal decision, the order is submitted to a referendum of the affected producers. ${ }^{110}$ Any handler sub-

103. Id. § $900.9(\mathrm{~b})$.

104. Id. $\$ 900.10$.

105. Id. $\S 900.12(\mathrm{a})$.

106. Id. $\S 900.12(\mathrm{~b})$.

107. Id. § 900.12(c).

108. Id. $\$ 900.13(\mathrm{a})$.

109. Id. $\$ 900.16$.

110. The order becomes effective if it is approved (a) by 50 per cent of the handlers (by volume) as evidenced by their signing a marketing agreement and (b) 
ject to an approved order may thereafter petition the Secretary either for an exemption from the order or for a modification of the order on the ground that "it is not in accordance with law."111 This proceeding, usually referred to as a (15)(A) hearing, is conducted as a formal adjudication. ${ }^{112}$

The Office of Hearing Examiners at the Department of Agriculture has collected statistics on the number of formal hearings conducted under the marketing order programs:

$\begin{array}{cc}\text { Fiscal Year } & \text { No. of Hearings }{ }^{113} \\ 1966 & 79 \\ 1967 & 81 \\ 1968 & 65 \\ 1969 & 45 \\ 1970 & 51\end{array}$

These statistics cover both original rulemaking hearings and (15)(A) hearings. A hearing examiner estimated, however, that 70-80 percent of the above hearings were rulemaking hearings.

by two-thirds of the producers (measured either by volume or per capita). 7 U.S.C. $\S 608 \mathrm{c}(8)$ (1970). The approval by the handlers may be dispensed with, however, if the Secretary determines that the refusal of the handlers to agree "tends to prevent the effectuation of the declared policy" of the Act and that the issuance of the order "is the only practical means of advancing the interests of the producers . . . pursuant to the declared policy" of the Act. Id. $\$ 608 \mathrm{c}(9)$. Not all marketing orders are approved at the referendum; some recent referenda orders have been narrowly rejected by producers. See Spearmint Oil Produced in Washington, Idaho and Oregon and Designated Parts of California, Nevada, Utah, and Montana, 36 Fed. Reg. 14389 (1971); Lettuce Grown in California, Arizona, Colorado, New Mexico, and Designated Parts of Texas, 37 Fed. Reg. 6103 (1972).

111. 7 U.S.C. \& $608(\mathrm{c})(15)(\mathrm{A})(1970)$.

112. The AMS files either an answer to the petition [7 C.F.R. $\S 900.52 \mathrm{a}$ (1972)], or an application to dismiss the petition if it feels it does not comply with procedural regulations, is not filed in good faith, or is filed for purposes of delay. Id. $\$ 900.52$ (c). An oral hearing on the record is held [id. $\$ 900.60]$ before an APA hearing examiner and there is subpoena power. Id. $\$ 900.62$. After the examiner prepares an initial decision (called a "report") [id. \$ 900.64(c)], exceptions may be filed, and a final decision is made in the name of the Department of Agriculture's judicial officer. In the event the handler is dissatisfied with the decision, judicial review is available in the federal district court for the district in which the handler is au inhabitant or where he has his principal place of business. 7 U.S.C. $\$ 608 c(15)(B)(1970)$.

Because a section (15)(A) proceeding provides an administrative remedy, it clearly prevents direct judicial review of the order itself by unhappy handlers. For many years it was thought that the rulemaking decision was therefore free from direct judicial review, but with the relaxation of the requirements of standing it is possible that other groups may be able to obtain direct judicial review of such orders. But see Rasmussen v. Hardin, No. 25,668 (9th Cir., Mar. 29, 1972), holding that consumers lack standing to attack milk marketing orders on the theory that the Act specifically prohibits judicial review.

113. These figures are not comparable with FDA statistics because the Department of Agriculture holds hearings in both controverted and non-controverted proceedings. In contrast FDA only holds hearings in the most controverted of cases. See text accompanying note 74 supra. 
An FDA attorney, after learning that formal evidentiary hearings were held by Agriculture as virtually the first stage of the rulemaking process, commented that he wondered how they ever finished a proceeding. Actually, the Agriculture hearings are not unduly protracted. Even in a fairly complex proceeding involving western head lettuce that is grown in a number of discrete growing areas in several states and distributed on a nationwide basis, hearings held in two cities resulted in a transcript of 2,160 pages. A relatively controversial proposal to expand a milk marketimg area into new areas in New England generated a transcript of 1,000 pages in four days of testimony. The longest hearing held by the Department was back in the 1950's and created a transcript of about 15,000 pages, but such an oversized hearing has not recurred, and most hearings are completed in a few days or less.

Unlike observers of the FDA hearings, persons familiar with the AMS formal rulemaking hearing see little reason to eliminate it. The consensus is that while the hearings have problems, the advantages outweigh the disadvantages, and less formal proceedings might create new problems. And unlike the formal hearings held by FDA, the Department of Agriculture hearings appear to serve several purposes: ${ }^{114}$

a. Development of factual information. The information needed to review and formulate a marketing order is narrow and detailed. In which towns does a dairy sell the bulk of its milk? Who else supplies the milk sold in those towns? Where does a dairy obtain most of its milk and at what prices? At what time of the year does lettuce grown in Arkansas Valley, Colorado mature and where is it sold? What is the anticipated production of tomatoes in Florida during a period beginning with the third week of May? Has the influx of Latin immigrants into Florida smce 1955 sufficiently increased the demand for riper limes in the production area as to justify specified amendinents to a marketing order? Answers to such questions may vary from time to time. A drought in Iowa may have a broad but temporary impact on milk inarketing patterns. A late freeze in Florida may markedly reduce the anticipated production of tomatoes, thereby justifying a smaller minimum acceptable size. Because market orders may be based on incomplete and shifting information, proponents of an order may believe that "disorderly marketing conditions" are mucli greater than they really are. At the hearing persons may appear and explain what they are actually doing or where they actually sell their product. The liearing conducted at the early stage of the marketing order proceeding is thus a reasonably efficient method of developing information. Such information almost certainly would not be within the knowledge of a

114. Compare text accompanying notes 81-86 supra. 
commodity marketing specialist located in Washington, D.C., and may not be available to persons actively engaged in producing or handling the regulated commodities. The usefulness of the record as a source of information is attested to by marketing specialists who rely on the testimony adduced at the hearing in formulating a recommended decision. Summaries of testimony may be prepared by the specialist; crossexamination is reviewed carefully. Here the record serves as the basis for decision in fact as well as theory.

b. Informing affected persons. The formal hearings occasionally serve an educational function as well as an evidentiary one. A marketing order may directly affect a large number of small handlers and farmers who may not fully understand the implications of the proposal until it is explained at the hearing. Solnetimes, answers to questions by these persons help to inform them how the proposed order may operate. In some instances, questions put to witnesses on cross-examination seem to be designed to make sure that a hostile witness is aware of the good poimts of the proposal. In the sampling of transcripts examined for this study, lowever, this function seemed relatively minor. Most of the participants appeared aware of the implications of the proposals and had taken a firm position in advance on the proposal.

c. Allowing participation at a meaningful stage of the decisional process. There is a town meeting or participatory democracy flavor to some of these hearings. The hearing examiners emphasize that this is the opportunity for everyone to make known his views so that they may be considered in the decisional process. The hearing certainly provides this opportunity, and as a result some testimony is mcluded which is liardly relevant to the strict purpose of the hearing. A farmer may testify that he farms so many acres and that he is a rugged individualist who does not want a bureaucrat telling him what to grow. A representative of a consumer group may appear and object to a marketing order for lettuce on the ground that the retail price of lettuce is already too high. ${ }^{115}$ Farm labor representatives may also appear and ask that they be permitted to sliare in any additional profits the growers may make as a result of the marketing order. ${ }^{116}$ Reflecting on this function of the hearing, one marketing specialist commented that he thought it necessary that the Department take no position on the merits of the proposal at this stage in order to avoid creating the impression that a decision lad already been made.

115. This witness offered as exhibits lettnce bought at various stores at various prices. The hearing examiner hastily explained that the Department did not have facilities to store spoilable exhibits.

116. Given the statutory purpose of the entire marketing order program-to improve prices paid to farmers-the views of these nonfarm groups are given little weight by the AMS in its rulemaking decisions. 
It is probable that the type of information needed by the AMS for a reasoned decision could be obtained by devices other than a formal evidentiary hearing. Much the same information could probably be obtained from a field investigation and questionnaires to producers and handlers for example; a legislative-type oral hearing might then suffice to permit the affected persons to express their views on the need for the proposed order and the correctness of facts underlying the proposed order. It seems probable that such procedures would be more expeditious than a formal hearing, though any firm generalization is hazardous. The possibilities of experimentation under the present statute appear limited, however, since it requires that the Secretary's findings be based "upon the evidence introduced at the hearing."117 The prospect that the AMS produce at the hearing the evidence and information obtained from a prior investigation is unappealing in light of the FDA experience discussed earlier. ${ }^{118}$

Certainly, a formal hearing is not the only way to develop detailed information about narrow or local issues. The Interstate Commerce Commission administers a grant of rulemaking authority involving problems somewhat similar to the Department of Agriculture marketing order prograin, but the ICC only rarely uses formal evidentiary hearings. Section 203(b)(8) of the Interstate Commerce Act exempts from regulation "the transportation of passengers or property in interstate or foreign commerce wholly within a municipality or between contiguous municipalities or within a zone adjacent to and commercially a part of any such municipality or municipalities." ${ }^{119}$ By regulation, the ICC has established a general definition of a commercial zone based on the population of the municipality. ${ }^{120}$ In addition, however, the ICC has specifically designated the commercial zones of some 36 cities, ${ }^{121}$ based on ad hoc determinations that the areas so designed are in fact commercially a part of the municipality. These ad hoc commercial zone determinations constitute a very particularized kind of rulemaking for which knowledge of the precise characteristics of an area is necessary. ${ }^{122}$ There are no specific procedural require-

117. 7 U.S.C. $\& 608 \mathrm{c}(3)(1970)$.

118. See text accompanying notes 40-73 supra.

119. 49 U.S.C. $\$ 303(\mathrm{~b})(8)$.

120. See 49 C.F.R. $\$ 1048.101$ (1971). For example, the commercial zone for a municipality with a population of 2,500 or less extends two miles into unincorporated areas surrounding it; up to 25,000 , the zone is three miles, and so forth.

121. 48 C.F.R. $\$ \S 1048$, et seq. (1972).

122. As an example, the first few lines of the defimition of the Washington, D.C. commercial zone are as follows:

Beginning at the intersection of MacArthur Boulevard and Falls Road (Maryland Highway 189) and extending northeasterly along Falls Road to its junction with Scott Drive, thence west on Scott Drive to its junction with 
ments for designating commercial zones. As a practical matter the ICC usually relies on its modified procedures so that all evidence is presented in written form. There is no oral hearing, and, of course, no cross-examination. In at least two commercial zone determinations, however, the ICC decided to hold formal evidentiary hearings, including cross-examination. In these instances, not only were the issues local and complex, but they were also the subject of intense controversy. ${ }^{123}$

The determinations made by the ICC and those made by the Department of Agriculture are similar, but there are significant differences. The pattern of marketing fluid milk and the available supplies of perishable agricultural commodities may be more difficult to establisli accurately by written procedures than are commercial zones. More written information may be available on the latter, which are likely to remain more stable over a period of time.

Further, some of the town meeting feeling of the present hearings would probably be lost even if a legislative-type hearing is substituted. One advantage of the formal hearing in the marketing order program is that it comes early in the administrative process, presumably before the agency personnel have firmly decided on a prograin. A legislativetype hearing held after a substantial departmental investigation may not be the saine thing, or more important, may not seem to be the same thing to the persons involved.

On balance, there seems to be little basis for recommending drastic change in the liearing procedures of the Department of Agriculture. While less formal procedures might be more efficient, the Department has evolved procedures which permit the handling of a large volume of rulemaking-on-a-record proceedings in a reasonably expeditious and efficient manner.

\section{The Department of Interior}

The Department of Interior administers one statute, the Federal Metal and Nonmetallic Mine Safety Act of $1966,,^{124}$ which requires the

Viers Drive, thence west on Viers Drive to its junction with Glen Mill Road ...

49 C.F.R. \& 1084.4 (1971). Commercial zone determinations require knowledge of areas of commercial development, of the physical locations of stores and facilities, of the buying habits of people in specific localities, and other such factors. An aerial photograpl of the area in question is persuasive evidence on physical locations and an examination of telephone books may provide information on services available in a specific location.

123. These proceedings involved the establishment of commercial zones in the Minneapolis-St. Paul area and in Seattle-Tacoma, Washington. Commercial Zones and Terminal Areas, 107 M.C.C. 473 (1968); Seattle-Tacoma, Washington, Commercial Zone, 111 M.C.C. 718 (1970).

124. 30 U.S.C. $\$ \$ 721$ et seq. (1970). 
Secretary of Interior, in certain circumstances, to hold an on-the-record hearing in connection with rulemaking. ${ }^{125}$ Section 725 of the Act authorizes the Secretary of Interior to develop and promulgate "after consultation with advisory committees, . . . health and safety standards for the purposes of the protection of life, the promotion of health and safety, and the prevention of accidents in mines ..." If the proposed standard is approved by an advisory committee ${ }^{126}$ it may be put into effect without a hearing. ${ }^{127}$ If it is not approved, however, the Secretary may proinulgate a standard only after a notice is published in the Federal Register and "a public hearing (subject to the Administrative Procedure Act)" is held, if requested by an interested party. The promulgation of such standards, the statute makes clear, must be pursuant to an on-the-record procedure. ${ }^{128}$

Three basic standards have been promulgated under this Act. ${ }^{129}$ In each instance, the Secretary created an advisory committee as required by the statute, and the committee was asked to formulate a mutually acceptable proposed mandatory standard. If the committee agreed on a proposal and the Department concurred, the proposed standard was promulgated without a hearing pursuant to section 725 (e). Where the Department concluded there were oinissions, in connection with radiation controls, for example, or where there was no committee agreement, the Department issued a proposed standard and asked for comment. Most comments were in the form, "unless you change the proposal to meet our objections as set forth in this letter, we request a formal hearing." In some imstances, the Department revised proposed standards in light of comments, or made clianges in them with which the parties ultimately agreed, so that the requests for liearing were withdrawn. In each case a formal liearing was avoided:

125. The Department of Interior, along with the Department of Health, Education and Welfare, have regulatory responsibilities under the Federal Coal Mine Health and Safety Act of 1969, [id. $\$ \$ 801$ et seq. (1970)] which is partially patterned after the Metal and Nonmetallic Mines Safety Act, id. $\$ \S 721$ et seq. (1970). The Coal Mine Act is discussed in section III infra, at notes 195-205.

126. The advisory committee is composed of an equal number of representatives of workers and operators of mines, plus one or more representatives of mine inspectron or safety agencies of the States. 30 U.S.C. \$ 726 (1970).

127. Id. $\$ \$ 725(\mathrm{~d}),(\mathrm{e})$.

128. Section 725 uses language very similar to section 701 (e)(3) of the Federal Food, Drug and Cosmetic Act, 21 U.S.C. 371(e)(3) (1970). The hearing is for the purpose of receiving "evidence relevant and material to the issues" raised by the objections. The Secretary's decision must be based "only on substantial evidence of record at such hearing" and, on judicial review, the Secretary's findings of fact "if supported by substantial evidence, shall be conclusive." 30 U.S.C. $\$ \S 725$ (d)(2), (3) (1970).

129. 30 C.F.R. $\S \S 55,56 \& 57$ (1972). 
Thus, the formal, on-the-record procedure has been used as a club to force a consensus on mandatory safety standards for miners. The negotiating procedure actually followed is not unlike that which takes place in connection with Food and Drug Administration rulemaking proposals, though the formalization of the advisory committee procedure in the statute under discussion is unique.

\section{The Department of Labor}

The Department of Labor administers the Walsh-Healey Act $^{130}$ which requires rulemaking on a record. ${ }^{131}$ Section 1 of this Act requires that contractors selling more than $\$ 10,000$ worth of supplies or equipment to the United States stipulate that all persons employed in the performance of the contract be paid "not less than the minimum wages as determined by the Secretary of Labor to be the prevailing minimum wages" for employees doing similar work or employed in similar industries in the locality. ${ }^{132}$

Following Perkins v. Lukens Steel Co., ${ }^{133}$ which held that industry did not have standing to challenge wage determinations made by the Secretary under this Act, the Department was able to proceed without concern for judicial review; it established Walsh-Healey minima primarily upon the basis of confidential wage surveys conducted by the Bureau of Labor Statistics [BLS], though consultation and public hearing procedurcs were also used.

In 1952, Congress amended the Walsh-Healey Act to reverse the Lukens Steel holding and at the same time imposed the requirement that wage determinations must be made "on the record after opportunity for a hearing." ${ }^{134}$ These changes did not result in a major change in procedures the Secretary followed when making wage determinations. His regulations provided for a simplified on-the-record proceeding: it was unnecessary to swear witnesses, but cross-examination was permitted "of any witncss as may be required for a full and true disclosure of the facts," and objections to the admission or exclusion of evidence could be entertained. ${ }^{135}$ APA hearing examiners pre-

130. 41 U.S.C. $\$ \S 35-45$ (1970). The Department also administers the Fair Labor Standards Act [29 U.S.C. $\$ \S 201$ et seq. (1970)] which also contains an on-the-record requirement for industry committees. See note 23 supra.

131. 41 U.S.C. $\$ 39(1970)$.

132. 41 U.S.C. $\$ 35($ b) (1970). The Walsh-Healey Act also authorizes the Secretary to establish health and safety standards for government contractors. Such standards, however, may be promulgated under section 553 of Title 5 of the APA, 5 U.S.C. $\S 553(1970)$.

133. 310 U.S. 113 (1940).

134. 41 U.S.C. $\$ 43 a(1970)$.

135. 41 C.F.R. $\$ 50-203.20$ (1972). 
sided at the hearings, but the record was certified to the Secretary who issued a tentative decision.

Here, between 1952 and 1964, the Secretary apparently combined reliance on confidential BLS statistical imvestigations with an onthe-record proceeding. ${ }^{136}$ The entire program came to an abrupt halt, however, as a result of Wirtz v. Baldor Electric Co. ${ }^{137}$ The Secretary had proposed to establisli wage standards for the electric motor and generator industry. The information garnered by the BLS wage surveys was presented at the hearing in tabular form but the underlying data were not produced. Industry counsel objected, arguing that data collected by the industry contradicted BLS data and that some companies had improperly coinpleted the BLS questionnaire. The hearing examiner refused to order the questionnaires produced on the ground that they were confidential. The Secretary, concluding that the BLS data were reliable, issued a wage determination based entirely on the summary determinations drawn from the BLS data. ${ }^{138}$ Relying on the early decision of Powhatan Mining Co. v. Ickes, ${ }^{139}$ the Court of Appeals for the District of Columbia concluded that since impeaching testimony of probative value ${ }^{140}$ liad been introduced, the Secretary could not rely solely on the BLS tabulations without their being supported by some reliable supporting evidence. Also, the industry had a right to rebut and cross-examine to obtain full disclosure of the facts, and thus the agency, as a matter of law, had to make available the underlying data on which it relied, despite the claim of confidentiality.

Following this decision, the Department for all practical purposes abandoned the wage determination portion of its Walsh-Healey program. ${ }^{141}$ There have been no formal proceedings since 1964; the pro-

136. It has been noted that even on this basis there were long delays (often exceeding two years) between the proposal and the promulgation of a wage determination. See generally Modely, Patton \& Reilley, Problem Child Among Labor LawsThe Walsh-Healey Act, 1963 DUKR L.J. 205.

137. 337 F.2d 518 (D.C. Cir. 1964).

138. Id. at 521-23.

139. 118 F.2d 105 (6th Cir. 1941).

140. The court noted that the changes made by BLS in response to the NEMA survey were not de minimis, and that because NEMA had only checked a sampling of the BLS returns, an inference might be drawn that even more substantial errors existed.

141. Many wage determinations made before 1964 remain in effect but have become less and less relevant as wage levels have risen. The Department continues to modify Walsh-Healey minimum wage determinations when Congress raises the nation-wide minimum wage, so that all Walsh-Healey determinations are at least at the national minimum wage. But no new determinations reflecting wage standards above the statutory minimum wage have been undertaken. The Department continues to conduct rulemaking proceedings relating to hcalth and safety standards. In addition, the enforcement program for wage determinations continues. 
gram is dead and no one seems to have any particular desire to rehabilitate it.

The death of the program may be only partially attributable to the procedural problems created by the Baldor decision. The administration of the Walsh-Healey Act had been subject to some criticism from congressmen and from representatives of affected industry. Further, the need for the Act diminished after the Fair Labor Standards Act ${ }^{142}$ giving Congress the power to establish nation-wide minimum wage standards for products in interstate commerce, was upheld. ${ }^{143}$ It probably would not have been easy, however, to square the long continued practice of securing BLS data on a confidential basis with the Baldor court's concept of rulemaking on a record; the procedural problein thus undoubtedly contributed to the program's demise.

\section{The Federal Trade Commission}

The Federal Trade Commission and the Food and Drug Administration share the administration of the Fair Packaging and Labeling Act. ${ }^{144}$ This Act authorizes the agencies to establish standards for the characterization of package sizes, the placement of information on labels, and similar matters. Even though it is difficult to imagine policy questions which are less appropriate for a trial-type hearing, ${ }^{145}$ the Act requires proceedings conforming to section 701(e). The FDA and the FTC have avoided formal hearings, however, though both have promulgated substantive regulations. ${ }^{140}$ The FTC did

142. 29 U.S.C. $\$ \$ 201-219$ (1970).

143. Overnight Motor Transp. Co. v. Missel, 316 U.S. 572 (1942).

144. 15 U.S.C. $\$ \$ 1451-61$ (1970). The FDA administers this Act to the extent that it applies to foods, drugs and cosmetics; the FTC administers it for othcr products.

145. The FDA, for example, in explaining regulations relating to the location of the manufacturer's name on labels, said:

The Commissioner does not dispute that other placement provisions could have been adopted. It was impossible for the Commissioner to select a single location that would be agreeable to all parties for all good labels on the market. The law requires the Commissioner to select a uniform location for this information that would be conspicuous and suitable. A public hearing as to the best location is not required, nor would a hearing of opinions on other places where this information might be placed change the situation. Such opmions have already been presented to the Commissioner at grcat length. Since the statute provides that the selection of the uniform location shall be made by the Commissioner and not by popular vote, and since no snbstantial objection to his selection has been offered, it is found that there is no basis for a public learing on this issue . . . .

32 Fed. Reg. 13276, 13277 (1967).

146. There is an area of overlap between the broad provisions of the Federal Trade Commission Act [15 U.S.C. \$\$ 41 et seq. (1970)] and the narrower Fair Packaging and Labeling Act, 15 U.S.C. \$\$ 1454 et seq. (1970). Acting under the former statute, the FTC promulgated a proposed trade regulation rule requiring the disclosure of ingredients in detergents and a warning against the excessive use of 
schedule one formal hearing on objections to a regulation relating to disclosure of net weight of bars of soap, but a voluntary standard satisfactory to the Commission was worked out with the assistance of the National Bureau of Standards, and the request for a hearing was withdrawn.

The procedures followed by the Federal Trade Commission are patterned on those of the Food and Drug Administration, though the FTC appears to make it more difficult to obtain a formal hearing than does FDA. ${ }^{147}$

\section{The Department of Justice}

The Bureau of Narcotics and Dangerous Drugs (BNDD) of the Department of Justice is required to follow an on-the-record procedure when classifying narcotic or abusable drugs for regulatory purposes. Section 201(v) of the Federal Food, Drug and Cosmetic Act, enacted in $1965,{ }^{148}$ first vested in FDA the authority to classify drugs as depressant or stimulant and therefore subject to special regulation and control. Section 701(e $)^{149}$ was specifically made applicable to this determination. In determining whether a drug was subject to control, the Commissioner was required to find that the drug has a "potential for abuse."150 The FDA instituted proceedings under this statute to have the tranquilizers meprobamate and hbrium/valium classified, and formal evidentiary learings were held on these drugs. Before either of these proceedings was coinpleted, an Executive Order transferred administration of section 201(v) to the Bureau of Narcotics and Dangerous Drugs (BNDD) of the Department of Justice. The

detergents containing phosphates. The FTC proposed to follow the notice-and-comment procedures of APA section 553 [5 U.S.C. $\$ 553$ (1970)] rather than those specified by section 701(e) of the Food, Drug and Cosmetic Act, 21 U.S.C. $\S 371$ (e) (1970). Detergent manufacturers contended that ingredient disclosure falls exclusively under the Fair Packaging \& Labeling Act and that they could not be deprived of their right to a formal evidentiary hearmg merely by the agency deciding to proceed under the Federal Trade Commission Act. A judicial review of this controversy was dismissed, without a decision on the merits, on the basis that the action was premature.

147. The FDA regulation [21 C.F.R. $\$ 2.67$ (1971)] provides that objections, to trigger a hearing, "must be supported by reasonable grounds which, if true, are adequate to justify the rehef sought." The FTC regulation [16 C.F.R. $\$ 1.16(\mathrm{~g})$ (1971)] requires that the objections must be "supported by reasonable grounds which, if valid and factually supported, may be adequate to justify the relief sought." (Emphasis added).

148. Drug Abuse Control Amendments of 1965, Pub. L. No. 89-74, § 201(v), 79 Stat. 226.

149. Food, Drug and Cosmetic Act, 21 U.S.C. $\$ 371$ (e) (1970).

150. The Commissioner must also find that the drug in fact is a depressant or stimulant, and that its potential for abuse is a result of its depressant or stimulant effect. Drug Abuse Control Amendments of 1965, Pub. L. No. 89-74, $\$ 201(v), 79$ Stat. 226. 
meprobamate proceeding was completed on the basis of the hearing record created by FDA; a final order was issued and was upheld on judicial review. ${ }^{151}$ In the librium/valium classification, BNDD decided to hold a supplemental hearing on whether these drugs were being abused in connection with other, more powerful drugs. A hearing examiner was borrowed and a 13-day hearing was held, amassing a transcript of about 1,400 pages, mcluding extensive testimony of drug users. A final order was issued ${ }^{162}$ and the matter is presently pending on judicial review.

The Comprehensive Drug Abuse Prevention and Control Act of $1970^{153}$ superseded the 1965 Act. It creates five classes (called schedules) of narcotic or abusable drugs, depending on the relative potential for abuse and the extent of legitimate medical uses. ${ }^{154}$ The Act classifies numerous substances and gives the Attorney General authority to add or remove substances froin the various schedules. Apparently following the analogy of section 701(e) of the Food, Drug and Cosmetic Act, the Act requires these decisions to "be made on the record after opportunity for a hearing pursuant to the rulemaking procedures prescribed by" the Administrative Procedure Act. ${ }^{155}$

Before initiating a proceeding to reclassify a drug, the Attorney General must "request from the Secretary of Health, Education and Welfare a scientific and medical evaluation, and his recommendations," as to how the drug should be classified under the Act. The Secretary is directed to consider various medical factors in making his recommendation: the drug's pharnacological effect, if known; the state of current scientific knowledge regarding the drug; the risk to public health; whether the drug is likely to create psychic or physiological dependence; and whether the drug is an "immediate precursor" (a term defmed in the Act) of a substance already controlled under the Act. On such scientific and medical matters, the determinations of the Secretary "shall be binding on the Attorney General."150 If the Secretary concludes that the drug should not be controlled, the Attorney General may not control it. ${ }^{167}$ There are no procedures of any kind specified for the Secretary to follow in formulating his recommendation-not even rulemaking under section 553. In connection with the proceeding under the new Act to schedule librium and vahum,

151. Carter-Wallace, Inc. v. Gardner, 417 F.2d 1086 (4th Cir. 1969) cert. denied, 398 U.S. 938.

152. 36 Fed. Reg. 2555 (1971).

153. 21 U.S.C. $\$ 801$ et seq. (1970).

154. Id. $\S \S 811,812$.

155. Id. $\$ 811(\mathrm{a})$.

156. Id. $\$ 811(\mathrm{~b})$.

157. Id. 
the Secretary, without any public procedures at all, simply formulated his recommendation on the basis of information available to him.

In contrast, the statute requires BNDD to hold a formal evidentiary hearing on the three factors it is required to take into account in considering drug classification: the drug's actual or relative potential for abuse, its history and current pattern of abuse, and the scope, duration, and significance of abuse..$^{158}$ The legislative history indicates that this division of authority and divergence of procedures was intentionally created by Congress to strike a balance between law enforcement criteria and medical and scientific determinations in arriving at control decisions. ${ }^{159}$

A trial-type hearing appears to be a reasonable procedure for making findings as to the scope, duration and pattern of abuse for a particular drug. Such findings inust involve investigation of illicit or semi-illicit behavior on which reliable documentary or oral evidence may be difficult to obtain. For example, in the librium/valium proceeding conducted by BNDD under the 1965 statute, witnesses imcluded a convicted felon, and hearsay testimony was taken as to the activities of persons whose identities were only partially revealed. Cross-examination may be peculiarly useful in the evaluation of this kind of testimony, though each specific incident of drug abuse is only cumulative as to a finding of the pattern or scope of drug abuse. The House Report, however, did not rely on this possible justification for requiring an on-the-record proceeding. The Report instead relies on the justification that a hearing on the record provides affected parties an opportunity to be heard and permits judicial review. ${ }^{\mathbf{1 6 0}}$

In contrast to the BNDD determinations, the bimding determinations by HEW involve medical and scientific natters relating to the drug under consideration. A trial-type learing on such questions would likely bog down in a morass, the frequent fate of FDA section 701(e) hearings. ${ }^{161}$

There have been no formal hearings under the Comprehensive Drug Abuse Prevention and Control Act. Informal conversations with BNDD officials indicate a desire to avoid formal hearings whenever possible. BNDD hopes: (1) to engage in substantial negotiations with interested parties before a proposal is put forth, and thereby

158. Id. $\S 811(\mathrm{c})$. In the evaluation and recommendation process, the Secretary of HEW considers the other factors listed in the statute section $811(\mathrm{c})$ in addition to the medical and scientific information relevant to the factors to be considered by BNDD.

159. H.R. Rep. No. 91-1444, 91st Cong. 2d Sess. (3 U.S. Code Cong. \& Ad. News 4566,4589 (1970)).

160. Id.

161. See text accompanying notes $67-73$ supra. 
minimize the number of proposed schedule changes to which objection is made; (2) to give interested parties access to all information in BNDD files which may be produced at the hearing so that they may evaluate the probability of success in a public learing; (3) to act promptly in scheduling hearings and making final decisions after receiving the hearing examiner's report, so that the formal hearing procedure will not be used merely for the purposes of delay.

If these plans are carried out in practice, the number of hearings should be relatively sinall and hearings held considerably nnore manageable than FDA's section 701(e) hearings. In view of the lack of experience with hearings under this new statute and the possible justification because of the kind of testimony likely to be elicited in these hearings, any conclusion as to the desirability of the procedures specified in this statute would be premature.

\section{The Federal Maritime Commission}

The Federal Maritime Commission is empowered by section 17 of the Shipping Act of 1916 to prescribe "just and reasonable regulations or practices" for the handling and storing of shippers' property only after finding that current regulations or practices are unjust or unreasonable. ${ }^{162}$ The requirement that a "finding" be made may be construed as requiring an on-the-record procedure. Motivated at least partially by this argunent, ${ }^{163}$ the Commission conducted two formal evidentiary hearings during the survey period pursuant to section $17 . .^{104}$ These proceedings involved free time and demurrage practices in specific ports. Free time is the period (usually five or ten days) during which cargo may be left with the carrier without incurring storage

162. 46 U.S.C. $\$ 816(1970)$.

163. The section 17 proceedings, involving the establishment of reasonable regulations and practices that largely involve fees for specific services, bear more than a superficial relationship to ratemaking, and it is possible also that the agency was impressed with this analogy when it agreed to conduct these proceedings on the record.

In addition, the agency may have become gun-shy about informal rulemaking proceedings under section 17 as a result of its reversal in American President Lines Ltd. v. FMC, 317 F.2d 887 (D.C. Cir. 1962). The agency, after extensive correspondence with affected persons, announced the adoption of an interpretation [25 Fed. Reg. 13696 (1960)] relating to the demurrage charge general order, 46 C.F.R. $\$ 226$ (1972). On judicial review, the court held that the interpretation was in fact an amendment and was invalid for failing to comply with section 553 of Title 5, assuming that section 553 is applicable. There is a strong overtone in the court's opinion that it believed that the interpretation was unreasonable and would constitute a denial of just compensation for a service rendered if upheld.

164. Free Time and Demurrage Practices on Inbound Cargo at New York Harbor, 11 F.M.C. 238 (1970). Free Time and Demurrage Charges on Export Cargo, 13 F.M.C. 267 (1970). 
charges, called demurrage; demurrage charges are set on an ascending scale over a period of time in order to encourage shippers to pick up or deliver cargo proinptly. Each port is to some extent unique since a reasonable time period for picking up cargo may vary from port to port and strikes may entirely change the reasonableness of specific charges. For example, after a strike ends, consideration must be given to the extent of congestion on the docks and the difficulty of getting trucks into the pier area when deciding a reasonable time for penalty demurrage to begin running. An evidentiary hearing may be a sensible way to develop such information.

The number of participants in these two proceedings was large, and a full right of cross-examination was granted. The agency used extensive written procedures, however, and the hearings were concluded in a matter of days.

The Commission also conducted a formal evidentiary hearing in a rulemaking proceeding entitled Proposed Rule Covering Time Limit on the Filing of Overcharge Claims. ${ }^{165}$ A large number of carriers had developed contract provisions specifying that the carrier would consider a refund claim for overcharges only if filed within a certain period, usually six months. The FMC first conducted an informal rulemaking proceeding addressed to whether such clauses are subject to FMC regulation, whether they were inconsistent with other rights granted to shippers by the Shipping Act, and whether they operated in a discriminatory way. The FMC concluded that since it had only received written comment, there was no evidence on which a factual finding that the clauses operated unjustly or unreasonably could be made. One participant objected and requested a formal evidentiary hearing, which was granted. The FMC ultimately concluded that the clauses in question were just and reasonable. ${ }^{166}$

The evidentiary hearing in this proceeding developed useful factual information through testimony about the audit and control practices of large consignees relating to review of freight charges. Again, an evidentiary hearing was a sensible way to resolve the many complex factual problems in this proceeding.

\section{Agency Experience With Rulemaking-on-a-Record: Some Conclusions}

Congress has imposed mandatory trial-type hearings in rulemaking proceedings im a variety of different contexts which defy precise categorization. The over-all pattern, however, is not a random one. Most grants of rulemaking authority subject to an on-the-record re-

165. 12 F.M.C. 298 (1969).

166. Id. 
quirement involve broad and largely undefined power to regulate certain aspects of specific industries. The power to define what a specific product is to consist of, the power to determine that a product is hazardous and cannot be sold, the power to define what the production of a specific agricultural commodity is to be, the power to determine how limited production rights are to be allocated anong certain producers, the power to establish minimum wages for specific island industries, the power to levy assessments against specific agricultural handlers, the power to determine what drugs are subject to abuse and therefore should be subjected to rigorous governmental controls-all involve the heavy hand of the bureaucrat coming down on individual entrepreneurs in a supposedly free enterprise economy. ${ }^{107}$

The actual agency experience with these procedural requirements raises serious doubts about their desirability. At best, some agencies have learned to live with them, even though preferable procedures are probably available. At worst, these procedures have warped regulatory programs or resulted in virtual abandonment of them. It is surprising to discover that most agencies required to conduct formal hearings in connection with rulemaking in fact did not do so during the previous five years. The string of zeroes in the table on page 1280 is impressive. Thus, the primary impact of these procedural requirements is often not, as one might otherwise have expected, the testing of agency assumptions by cross-examination, or the testing of agency conclusions by courts on the basis of substantial evidence of record. Rather these procedures either cause the abandoninent of the program (as in the Department of Labor), ${ }^{168}$ the developinent of techniques to reach the same regulatory goal but without a hearing (as FDA is now trying to do), ${ }^{160}$ or the promulgation of noncontroversial regulations by a process of negotiation and compromise (as FDA historically has done $^{170}$ and Interior ${ }^{171}$ is encouraged to do). ${ }^{172}$ In practice, therefore, the principal effect of imposing rulemaking on a record has often

167. The one statute which seems to me not to fit this generalization very neatly is the Fair Packaging and Labeling Act, 15 U.S.C. $\$ \S 1454$ et seq. (1970). While the labeling of products is obviously an inportant aspect of economic activity, it tends to be on a very broad scalc, affecting a large number of manufacturers and retailers in essentially the same way. The imposition of rulemaking on a record in this statute probably may be traced to the united opposition of most business groups to this legislation when it was proposed.

168. See text accompanying notes 130-143 supra.

169. See text following note 49 supra.

170. See text accompanying note 68 supra.

171. See text following note 129 supra.

172. It probably does not need pointing out that valid and non-arbitrary regulations may be controversial. Rulemaking on a record is favored by industry attorneys, I suspect, precisely because it may help to impede or prevent the adoption of quite valid and reasonable regulations which are objectionable to their clients. 
been the dilution of the regulatory process rather than the protection of persons from arbitrary action.

It seems clear that rulemaking on a record required by section 701(e) of the Federal Food, Drug and Cosmetic Act ${ }^{173}$ has worked so poorly in the past that repeal is desirable. Repeal, however, faces formidable practical obstacles, since it may be opposed by large and articulate economic interests. Such opposition would probably be most intense if notice-and-comment rulemaking is proposed as a substitute; it seems reasonable, therefore, to suggest that a modified form of rulemaking on a record should be imposed in lieu of the present requirements. Also, much FDA rulemaking under section 701(e) involves the imposition of specific rules and standards on specific economic activity in order to implement broad legislative goals. As discussed below, this is precisely the kind of rulemaking on which Congress has traditionally desired to impose procedural requirements additional to pure notice-and-comment rulemaking.

The same degree of urgency does not appear to exist in colmection with the other grants of rulemaking authority now subject to an on-the-record requirement. Rather, it seems desirable to recommend in fairly general terms that agencies should seek to substitute less formal procedures for formal evidentiary hearings, to the extent it is practical to do so under current statutory requirements, and to recommend, again in general terms, that, where appropriate, agencies seek legislative amendments to permit the use of such procedures. The foregoing study reveals that trial-type procedures work best in connection with narrowly defined factual issues. The basic problem with formal rulemaking on a record is that it mandates such procedures in broad classes of proceedings, without regard to the existence of such issues. Ultimately, therefore, the goal should be the complete elimination of mandatory trial-type procedures in rulennaking. The modified rulemaking procedures recommended in section IV provide substantial protection agaimst arbitrary and capricious agency action, yet have substantial advantages in terms of flexibility and efficiency.

\section{III}

RECENT STATUTORY DEVELOPMENTS IN RULEMAKING: ATtEMPTS to DEVELOP A HALFWAY HoUSE BeTWEEN Formal AND INFORMaL ProceduRES

Notice-and-comment rulemaking has often been praised as providing a fair and efficient procedure. ${ }^{174}$ The basic theory underlying

173. 21 U.S.C. $\& 341$ (1970).

174. See, e.g., 1 K. Davis, Administrattve LaW Treatise, $\$ 6.15$ (1968). 
these procedures seems unquestionably sound: Protection against arbitrary or ill-considered rules is provided largely by the requirement that the agency issue a notice of proposed rulemaking and solicit feedback in the form of written comments by persons affected by the proposed rule before it is finally promulgated. ${ }^{175}$ There are problems with notice-and-comment rulemaking, however, that may be traced to a recurring problein of the administrative process: the apparent insensitivity of agencies to communications addressed to them. A person adversely affected in some serious way by a proposed rule may find little solace in the opportunity to submit a written comment. He has no way of knowing whether it will be read by the person with the ultiinate power of decision, or indeed, whether it will be read at all. Further, even if his views are considered by the proper persons, he may feel that he should be entitled to a greater opportunity to participate in the rulemaking process than the mere opportunity to file written comment. On the other hand, agency personnel and others desiring a prompt implementation of a regulatory prograin usually have hittle sympathy with such concerns. They believe that the agency will be careful, fair, and thorough, and object to more formal procedures as unnecessary. They also suggest that formal procedures are proposed to create delay in rulemaking rather than to improve the end-product of the rulemaking process.

Congress becomes the battleground for these opposing views when a new statute granting rulemaking authority is being considered. To a surprising extent, Congress has been sympathetic to the fears expressed by persons who may be subject to regulation under a broad grant of rulemaking authority. As a result, Congress has sometimes required the agency to conduct a full scale formal on-the-record proceeding before promulgating rules. ${ }^{178}$ Fortunately, such occasions have been relatively infrequent. More often, Congress has imposed

175. There are exceptions to the written comment requirement in the A.P.A. The Administrative Conference, however, has recommended that written comment be obtained when not legally required. See Recommendation No. 16, adopted October 21-22, 1969, in 1 RECOMMENDATIONS AND REPORTS OF THE ADMINISTRATIVE CONEFRENCE OF THE UNITED STATES 23, 29 (1970). In addition, courts have been suspicious of rules promulgated without the opportunity for comment. See, e.g., Pharmaceutical Mfrs. Ass'n v. Finch, 307 F. Supp. 858 (D. Del. 1970); American President Lines, Ltd. v. Federal Maritime Bd. 317 F.2d 887 (D.C. Cir. 1962).

176. Statutes enacted during the past decade that require such procedures include the Fair Packaging and Labeling Act, 15 U.S.C. \$ 1451 et seq. (1970); the Federal Metal and Nonmetallic Mine Safety Act, 30 U.S.C. $\$ 721$ et seq. (1970); and the Federal Hazardous Substances Labeling Act, 15 U.S.C. \$ 1261 (1970). Two statutes, which give the Administrator the choice between using formal or informal procedures, are the Child Protection and Toy Safety Act of 1969, id., and the Poison Prevention Packaging Act of 1970, id. § 1471 (1970). 
additional procedural requirements, but has not gone all the way to require a formal evidentiary proceeding.

The raw material for this section is the recent flood of new legislation authorizing the creation of standards and rules by administrative agencies. Such statutes deal with a wide variety of problems of current concern, mcluding protection against hazaŕdous substances, color and food additives, air and water pollution, oil spills, vehicle safety, occupational safety and health (in specific industries such as coal mines and federal construction, or in all industries), poultry inspection, natural gas pipeline safety, poison prevention, and toy safety. In addition, legislation is now pending in Congress relating to pesticides, product safety, the safety of medical devices, a grant of general rulemaking authority to the Federal Trade Commision, and other subjects. In the debate on much of this legislation, affected industries have strongly urged that additional procedural requirements be included as a protection against arbitrary and unreasonable rules and standards.

The procedural provisions of these statutes are almost unbehevably chaotic. Congress has responded to requests for additional procedural rights and safeguards for rulemaking in a totally ad hoc fashion. Statutory descriptions of procedures vary widely depending on the Committee in which the bill originated and the pressures behind its passage. What is remarkable is that in only a relatively few recent statutes did Congress grant broad rulemaking authority without imposing some kind of additional procedural requirement. ${ }^{177}$

The various procedural innovations specified by Congress in these statutes may be broken down into several broad categories, although, as described below, there is often some ambiguity in the language of the Acts and some overlap in the categories.

\section{A. The Requirement of Consultation}

The first category involves informal rulemaking with the proviso that the agency must consult with some specific person or group. ${ }^{178}$ Since consultation may be informal, or even written, such requirements may add little to the requirements of the Administrative Procedure Act. On the other hand, considerable delays may arise if formal con-

177. Such statutes include the Clean Air Act Amendments of 1970, 42 U.S.C. $\S \S 1857 \mathrm{a}, 1857 \mathrm{~g}(\mathrm{a}), 1857 \mathrm{~h}$ (1970); the Egg Products Inspection Act, 21 U.S.C. $\S \S 1031,1034$ (1970); and 21 U.S.C. $\S \S 134,134 \mathrm{f}$ (1970) (act dealing with livestock and poultry diseases).

178. Such a consultation requirement recently gave rise to a minor controversy when the Coast Guard and its parent agency, the Department of Transportation, unsuccessfully objected to a vessel safety bill provision now pending in Congress on the ground that the agencies to be consulted should not be specifically named in the legislation. S. Rep. No. 92-724, 92d Cong., 2d Sess. 26 (1972). 
sultation procedures involve the preparation of written monographs and formal recommendations. Furthermore, the language in several statutes is very general and imprecise. The Animal Welfare Act of $1970,{ }^{170}$ for example, authorizes the Secretary of Agriculture to establish standards for the lrumane handling of cats, dogs and other animals acquired for research purposes. ${ }^{180}$ Before promulgating standards, the Secretary inust "consult and cooperate with other Federal departments, agencies or instrumentalities concerned with the welfare of animals used for research [or] experimentation . . ."181

\section{B. Advisory Committees}

Several statutes require the agency to create and consult with a committee before promulgating regulations, or require the agency to do so upon request of an affected person. For instance, the Color Additive Amendments of 1960 require the Commissioner of the FDA to appoint an advisory committee of experts selected by the National Academy of Sciences to advise him in making scientific judgments about the carcinogenic properties of color additives. ${ }^{182}$ The affected person as well as representatives of the agency have the right to consult with the advisory committee. ${ }^{183}$ A similar committee, which must include one or more representatives from land-grant colleges, considers tolerances for pesticide residues on raw agricultural commodities. ${ }^{184}$

179. 7 U.S.C. § 2131 et seq. (1970).

180. Id. § 2143.

181. Id. § 2145. The Water Quality Improvement Act of 1970 [33 U.S.C. $\S 1151$ et seq.] authorizes regulations to be promulgated controlling the dumping of sewage from vessels. Id. \$ 1163. The agency must first consult "with the Secretary of State; the Secretary of Health, Education \& Welfare; the Secretary of Defense; the Secretary of the Treasury; the Secretary of Commerce; other interested Federal agencies, and the states and industries interested; and otherwise comply with the requirements of Section 553 of Title 5 " before issuing standards and regulations. Id. $\$ 1163(\mathrm{e})$. The Clean Air Act of 1967 [42 U.S.C. $\$$ 1857] and the Clean Air Act Amendinents of 1970 [Pub. L. No. 91-604, 84 Stat. 1676 (codified in scattered sections of 42, 49, 50 App. U.S.C.)] contain broad grants of rulemaking authority which are subject to qualifications such as "after cousultation with appropriate State and local authorities" [applies to definitions of a quality control region, 42 U.S.C. $\$ 1857 \mathrm{c}-2$ (c) (1970)] or "after consultation with appropriate advisory committees and Federal departments and agencies." [apphies to the developinent and dissemination of information on air pollution control techniques, id. \$1857c-3(b).]

182. 21 U.S.C. $\& 376(b)(5)(D)(1970)$.

183. Id.

184. 21 U.S.C. $\$ \$ 346 \mathrm{a}(\mathrm{e}),(\mathrm{g})(1970)$. Similarly, the Contract Work Hours and Safety Standards Act [40 U.S.C. $\$ 333(1970)$ ] requires the Secretary of Labor, before establishing einployee safety standards for federal construction, to consult with an advisory committce composed of three building trades employee representatives, three persons representing contractors, and three public representatives "selected on the basis of their professional and techincal competence and experience in the construction health and safety field." 40 U.S.C. $\$ 333(\mathrm{e})(1)(1970)$. See also Federal Meat Inspectiou Act of 1970, 21 U.S.C. $\S \S 601,607$ (c), 661 (1970). 
Administrative agencies have also sometimes voluntarily established procedures for consulting with affected groups as an aid in rulemaking. The proposed efficacy-review study for over-the-counter (OTC) drugs by the Food \& Drug Administration, for example, contemplates monographs prepared by advisory review panels on the efficacy of classes of OTC drugs. The panels are to be composed of "qualified experts (appointed by the Commissioner) and may include persons from hists submitted by organizations representing professional, consumer and imdustry interests." 185 The monographs so prepared are then subject to an elaborate review procedure: the panel monograph is reviewed by the agency and published as a proposed monograph; after an opportunity for written comment, it is republished as a tentative final monograph; if objection is made, the Commissioner (personally and not by delegated representative) then conducts a threehour legislative-type oral hearing before the fimal monograph is published. ${ }^{180}$

Advisory panels were also used in the earlier National Academy of Sciences-National Research Council drug efficacy review study now being implemented by the FDA, ${ }^{187}$ but they were used in a significantly different way. ${ }^{188}$ In the earlier NAS-NRC study, preliminary decisions were made by panels selected exclusively by the National Academy of Sciences-National Research Council. Members were physicians, usually with some academic counection; none were representatives of the affected industry as such. Drug companies had only a limited participation in the review process: they were requested to submit all available data and evidence as to the efficacy of the drug, but did not participate in the review process. The panels met privately and reached their decisions in secrecy. The names of the members of the panels were not even disclosed until after the study was completed. The NAS-NRC panel recommendations were not made public; rather they were reviewed by FDA, revised if necessary, and the result of the review was then published. ${ }^{189}$

185. Prop. reg. 21 C.F.R. $\$ 130.301(a), 37$ Fed. Reg. 85, 87 (1972).

186. Id. $\$ \S 130.301(5)-(9)$.

187. This study covered primarily prescription drugs though a few OTC substances were also reviewed. The new study covers OTC drugs not considered in the earlier study.

188. The OTC study was apparently designed to meet some of the criticisms of the earlier study.

189. If the drug was classed as other than effective, it liad to be removed from the market within specified time periods, depending upon the classification, unless evidence of effectiveness was established. The drug company was entitled to a hearing on the question of effectiveness only if, within the specified period, it presented "adequate and well-controlled clinical investigations" demonstrating that there was a genuine and substantial issue of fact as to the efficacy of the drug. 35 Fed. Reg. 7250 


\section{The Requirement of an Oral Hearing}

Another common kind of provision is one that permits section 553 rulemaking but specifies that an oral hearing or an opportunity for oral presentation of views must be provided. For instance, the Natural Gas Pipeline Safety Act of $1968^{180}$ provides that:

The provisions of subchapter II of chapter 5 of Title 5 shall apply to all orders establishing, amending, revoking or waiving compliance with, any standard established under this chapter. The Secretary shall afford interested persons opportunity to participate fully in the establishinent of such safety standards through submission of written data, views, or arguments with opportunity to present oral testimony and argument.

Other statutes require a "public hearing."101 In context, it seems fairly clear that an oral hearing was intended. Several statutes are ambiguous. The Contract Work House and Safety Standards Act, ${ }^{102}$ for example, states that regulations shall be "based on proceedings pursuant to section 553 of Title 5 , provided that such proceedings include a hearing of the nature authorized by that section."193 Presumably, a written submission is a "hearing" authorized by that section, but conceivably an oral submission is what was contemplated. Equally ambiguous is a bill now pending before Congress that requires the Secretary of the Department of Transportation to publish proposed rules and regulations and "permit interested persons an opportunity for a hearing."194 Neither the statute nor the legislative history indicates what kind of hearing is contemplated: a written submission, an oral submission, or a trial-type procedure all fit within the statutory language.

(1970). To date no hearings have been held. The entire NAS/NRC review program has been plagued with delay and litigation.

190. 49 U.S.C. \& 1672(d) (1970). See also Wholesome Poultry Products Act, 21 U.S.C. $\$ \S 451,463$ (c) (1970); The Federal Railroad Safety Act of 1970, 45 U.S.C. $\S \S 421,431$ (b) (1970).

191. For example, the National Emission Standards Act of 1967 [42 U.S.C. $\S \S$ $1857 \mathrm{f}-1$ et seq. (1970)] requires such a hearing before the administrator may determine whether specific State standards are more stringent than federal standards. Id. \& 1857f6a(b). The Clean Air Act Amendments of 1970 [Pub. L. No. 91-604, 84 Stat. 1676, codified in scattered sections of 42, 49, 50 App. U.S.C. (1970)] requires the Administrator of the Environmental Protection Agency to establish national primary and secondary ambient air quality standards [42 U.S.C. $\$ 1857 \mathrm{c}-4$ (1970)], and the States are required, "after reasonable notice and public hearings," to prepare and adopt plans to implement these standards. Id. $\& 1857 \mathrm{c}-5$. The Secretary is authorized to prepare and adopt implementation plans if a State fails to adopt satisfactory ones; when doing so a "public hearing" nust be leeld in the affected State. Id. § 1857c-5(c).

192. 40 U.S.C. \& 333 (a) (1970).

193. Id.

194. H.R. Rep. 3140 , 92d Cong., 2d Sess. $\S \S 102(4)(B),(C)$ (1972). 


\section{Mixed Procedures}

Another category of procedures defies precise categorization. They may arise either from a conscious attempt by Congress to combine features of both formal and informal rulemaking or by agency response to procedural requirements that are so ambiguous it is impossible to ascertain what procedures Congress intended the agency to follow.

\section{Federal Coal Mine Health and Safety Act.}

Under the Federal Coal Mine Health \& Safety Act of $1969,{ }^{195}$ the Secretary of Interior is authorized to promulgate mandatory safety standards for coal mines. ${ }^{198}$ The Secretary of Health, Education and Welfare is authorized to create inandatory health standards for the protection of miners, and to transmit them to the Secretary of Interior, who "shall" promulgate them. ${ }^{197}$ Both secretaries are broadly directed to consult with interested Federal and State agencies, representatives of coal mine operators, miners and other interested persons in formulating these standards. Thereafter, proposed mandatory standards of both types nust be published, and a period provided for comment. ${ }^{198}$ Any interested person may file an objection and request a "hearing"199 which is to be a "public hearing for the purpose of receiving relevant evidence."200 Within 60 days after the liearing is completed, the appropriate Secretary shall "make findings of fact which shall be public."201 This language is anbiguous, and has some connotations of a formal rulemaking on a record proceeding.

Section 816 of the Act provides that "any order or decision" of the Secretary may be subject to judicial review in the court of appeals "for the circuit in which the affected mine is located" and the petition for review is to be heard on the record made before the Secretary, which is to be certified and filed in the court. ${ }^{202}$ Further, "the findings of the Secretary . . . if supported by substantial evidence on the record considered as a whole, shall be conclusive."203 Section 956 of Title 30 adds to the ambiguity by stating that "except as otherwise provided in this chapter, the provisions of [the Administrative Procedure

195. 30 U.S.C. $\$ 801$ (1970).

196. $I d . \S 811(\mathrm{a})$.

197. $I d . \S 811(\mathrm{~d})$.

198. Id. $\& 811(\mathrm{e})$.

199. Id. \& 811(f).

200. Id. \& $811(\mathrm{~g})$.

201. Id.

202. Id. § 816(a).

203. Id. $8816(\mathrm{~b})$. 
Act] shall not apply to the making of any order, notice, or decision made pursuant to this chapter."204 Grammatically, it is arguable whether promulgation of mandatory standards should be considered either as an "order or decision" under section 816 or as an "order, notice, or decision" under section 956. This language may refer only to orders or decisions addressed to a specific mine which are authorized by other sections of the Act. That this is a reasonable construction for section 816 (and therefore for section 956 as well) appears from the reference to the "affected mine" in section 816 which has no clear antecedent. The legislative history sheds little light on the procedures to be followed in establishing mandatory standards.

Both HEW and Interior have taken the position that the statute does not require a formal evidentiary hearing. In recent hearings under this Act, both Departments have attempted to blend informal rulemaking with the specific language of the Act. ${ }^{205}$

\section{Occupational Safety and Health Act.}

The Occupational Safety and Health Act of $1970,{ }^{200}$ authorizes the Secretary of Labor within two years to promulgate as an occupational safety or health standard any "national consensus standard" and "established Federal standard."207 These terms are defined by the Act so as to include standards which are unlikely to be controversial. Such standards are to be promulgated "without regard to [the Administrative Procedure Act] or to the other subsections of this section."

The promulgation of other new standards, however, and the revision of standards proinulgated under section 655(a) (which obviously may be highly controversial) are governed by several specific statutory requirements: First, either on the basis of his own informa-

204. 30 U.S.C. \& 956 (1970).

205. The HEW procedures were described as follows:

The hearing shall be conducted in an informal, orderly manner. Persons making statements need not be sworn or make affirmation. Each party shall be given an opportunity to make a statement concerning the issues under consideration, an opportunity to make supplementary statements which may include comments on or rebuttal of other parties' views, and an opportunity to make recommendations concerning the issues in any of his statements. Any party may appear in person or by counsel.

A verbatim transcript of the proceedings of hearing sessions will be maintained. All written statements, charts, tabulations, and other data shall be received in the record. The Chairman shall submit to the Secretary the verbatim transcript ... together with recommended findings of fact. Within 60 days after the completion of the hearings, findings of facts concerning the issues presented at the hearing will be made public. Thereafter, mandatory health standards for surface work areas of underground coal mines and surface mines, with such modifications as are appropriate, will be transmitted to the Secretary of the Interior for promulgation.

36 Fed. Reg. 13172 at 13173 (1971).

206. 29 U.S.C. $\$ 651(1970)$.

207. Id. \& 655(a). 
tion or from investigation of written requests from others, the Secretary must "determine that a rule should be promulgated in order to serve the objectives of this chapter." The Secretary may employ an advisory committee, but this is discretionary. ${ }^{208}$ Next, a proposed rule promulgating, modifying or revising the occupational safety or health standard must be published and a period of 30 days provided for comment; ${ }^{209}$ any interested person may file a statement objecting to the rule and "requesting a public hearing." The Secretary must then publish a notice "specifying a time and place for such hearing."210 The actual mechanics of the hearing are not described. However, when promulgating a standard the Secretary must "mclude a statement of the reasons for such action."211 Any person adversely affected may file a petition challenging the validity of the standard in the court of appeals for the circuit where the person resides. On review "the determinations of the Secretary shall be conclusive if supported by substantial evidence on the record considered as a whole." ${ }^{212}$

The last quoted clause seems to contemplate an on-the-record proceeding. The Department, however, relying on rather helpful language in the legislative history, ${ }^{213}$ determined that a legislative-type hearing satisified the Act. Its procedural regulations implementing the Act state: ${ }^{214}$

The oral hearing shall be legislative in type. However, fairness may require an opportunity for cross-examination on crucial issues. The presiding officer is empowered to permit cross-exammation under such circumstances. The essential intent is to provide an opportunity for effective oral presentation by interested persons which can be carried out with expedition and in the absence of rigid procedures which might unduly mipede or protract the rulemaking process.

The hearing is to be conducted by an APA hearing examiner, who is specifically authorized $\mathrm{m}$ his discretion, to permit cross-examination. The record upon which the Secretary acts consists of "the transcript, together with written submissions on the proposed rule, exhibits filed during the hearing, and all past hearing comments, recommendations, and supporting reasons." ${ }^{215}$ The rule or determination by the Secretary

208. Id. $\$ 655(\mathrm{~b})(1)$.

209. Id. $\$ 655(\mathrm{~b})(2)$.

210. Id. $\$ 655(\mathrm{~b})(3)$.

211. Id. $\S 655(\mathrm{e})$.

212. Id. $\$ 655(\mathrm{f})$.

213. Both the Senate committee report and the Conference Report support the Department's position. See 3 U.S. CODE CONG. \& AD. NEws 5177, 5182, 5230 (91st Cong., 2d Sess., (1970).

214. 29 C.F.R. $\S 1911.15$ (2), printed in 36 Fed. Reg. 17506 (1971).

215. Id. $\$ 1911.17,36$ Fed. Reg. at 17508. 
must "be accompanied by a statement of findings and conclusions, as well as reasons therefor, upon all material issues of fact, law or discretion presented on the record." $" 216$

\section{National Traffic and Motor Vehicle Safety Act.}

The National Traffic and Motor Vehicle Safety Act of $1966^{217}$ authorizes the Secretary of Transportation to establish mandatory safety standards for motor vehicles and motor vehicle equipment. Such standards are to be established or modified "by order" and the Administrative Procedure Act is specifically made applicable to such orders. ${ }^{218}$ The operative sections do not contain the magic words "on the record" and do not require any specific procedure. The judicial review section of the Act, ${ }^{219}$ however, apparently contemplates a formal type of proceeding. After receiving a copy of the petition for review, "[t]he Secretary . . . shall file in the court the record of the proceeding on which the Secretary based his order, as provided in section 2112 of Title 28."220 Further, if the petitioner "applies to the court for leave to adduce additional evidence," shows that the evidence is material, "and that there were reasonable grounds for the failure to adduce such evidence before the Secretary," the court may order "such additional evidence (and evidence in rebuttal thereof) to be taken before the Secretary, and to be adduced upon the hearing," as the court may seem proper. The Secretary "may modify his findings as to the facts, or make new findings, by reason of the additional evidence so taken ..."221 Also, review of the order is to be "in accordance with" section 706 of Title 5, which permits review of factual findings on the basis of a substantial evidence test.

Despite these indications that a formal rulemaking proceeding was contemplated, DOT, in its procedural regulations, took the position that informal rulemaking was contemplated. ${ }^{222}$ An oral hearing may be granted or denied in the discretion of the agency; ${ }^{223}$ if granted, hearings are to be "informal, nonadversary, fact-fimding proceedings at which there are no formal pleadings or adverse parties [, and] any rule issued in a case in which an informal hearing is held is not necessarily based exclusively on the record of the hearing."224

216. Id. \& 1911.18(a), 36 Fed. Reg. at 17508.

217. 15 U.S.C. $\$ \$ 1381$ et seq. (1970).

218. Id. $\S \S 1392(\mathrm{a}),(\mathrm{b})(1970)$.

219. Id. $\$ 1394$.

220. Id. \& 1394(a)(1).

221. Id. $\$ 1394$ (a) (2).

222. 49 C.F.R. $\$ \S 553$, et seq. (1972).

223. Id. $\$ 553.25$.

224. Id. $\$ 553.27(\mathrm{a})$. 
In the test case under this legislation, standards relating to front seat head restraints, which were promulgated without an oral hearing, were upheld by the Court of Appeals for the District of Columbia. ${ }^{225}$ Recognizing the substantial ambiguities in the language of the statute, and treating the issue as solely being a choice between informal and formal rulemaking under the Administrative Procedure Act, the Court rehed in part on the legislative history and in part on a liberal construction of language to reach its result.

The Flammable Fabrics Act, ${ }^{226}$ which grants the Secretary of Commerce authority to promulgate flammability standards for fabrics, closely tracks the procedural sections of the National Traffic \& Motor Vehicle Safety Act of 1966 discussed above. The provisions of sections 551-559 of Title 5 are made applicable to rulemaking proceedings, but the judicial review provisions contemplate an evidentiary type of hearing. ${ }^{227}$ The procedural regulations adopted by the Secretary of Commerce 228 also state that hearings are to be "informal, nonadversary proceedings, at which there are no formal pleadings or adverse parties." ${ }^{322}$ Unlike the Motor Vehicle Safety Act regulations, however, an oral hearing will be held if requested by an interested party. ${ }^{230}$

\section{Pending Consumer Product Warranty Legislation.}

Perhaps the clearest example of an atteinpt to develop a modified rulemaking proceeding appears in S. 986 , a bill pending in the $92 \mathrm{~d}$ Congress. ${ }^{231}$ This bill creates rulemaking authority relating to minimum disclosure standards for written consumer product warranties, and also amends the Federal Trade Commission $\mathrm{Act}^{232}$ to sanction general rulemaking by that agency. Both of these grants of rulemaking authority are subject to ambiguous procedural restrictions.

a. Consumer warranties. The FTC is authorized to establish rules with respect to warranty disclosure requirements, the minimum duties to be undertaken by a supplier of goods under a warranty, and the application of such duties to different categories of consumer products. ${ }^{233}$

225. Automotive Parts and Accessories Assn. v. Boyd, 407 F.2d 330 (D.C. Cir. 1968).

226. 15 U.S.C. \$§ 1191 et seq. (1970).

227. Id. $\$ \$ 1193(\mathrm{~d}),(\mathrm{e})$.

228. 15 C.F.R. $\$ \$ 7.1$ et seq. (1972).

229. Id. § 7.9(b).

230. Id. $\$ 7.9$ (a). The Radiation Control for Health and Safety Act of 1968 [42 U.S.C. $\S 236 \mathrm{~b}$ at $\$ \S 263 f(b)$, (d) (1970)] closely parallels the ambiguous language of the Flammable Fabrics Act. See 15 U.S.C. $\$ \S 1193(d)$, (e) (1970).

231. S. 986, 92d Cong., 1st Sess. (1971).

232. 15 U.S.C. $\S \S 41$ et seq. (1970).

233. Id. §§ 102, 104, 109. 
The Commission is directed to establish such rules "pursuant to section 553, title 5, United States Code, upon a public record after an opportunity for an agency liearing structured so as to proceed as expeditiously as practicable."234 The Committee Report accompanying the bill indicated that the procedural provisions were meant to be a compromise between informal and formal rulemaking; interested parties participate in the rulemaking, but a formal oral hearing with crossexamination is not required as a part of all proceedings. Indeed, the Committee thought that in many situations interested parties could submit evidence in written form. According to the Committee, the procedure was designed to avoid the abusive use of cross-examination as a delay tactic. The report concluded that the intent of the Committee was "to avoid judicial-type proceedings for the resolution of nonfactual issues". ${ }^{235}$

b. FTC rulemaking authority. The FTC is also given a general power to promulgate "legislative rules defining with specificity acts or practices which are unfair or deceptive to consumers. . .."230 The procedures specified include an order of proposed rulemaking "stating with particularity the reason for the rule" and a period for comment. ${ }^{237}$ Further, the "Commission staff and other persons" are to be given "an opportunity to respond within a designated period of time to comments initially received." ${ }^{238}$ Sucl responses must be made publicly available. A learing may then be required if "there is a disparity of views concerning material facts on which the proposed is based." ing must be in accordance with sections 556 and 557 of the Administrative Procedure Act. The Commission "may permit cross exammation ... by one or more parties as representatives of all parties having similar interests."240 Again the Committee report elaborated on the meaning of this langnage. ${ }^{241}$

234. Id. § 109.

235. S. Rep. No. 92-269, 92d Cong., 1st Sess. 19-20 (1971).

236. S. 986, 92d Cong., 1st Sess. $\$ 206$ (1971).

237. Id.

238. Id.

239. Id.

240. Id.

241. The Commission would continue the proceedings only if there was 'a disparity of views concerning material facts upon which the proposed rule is based.' It is important to note that there must be a 'disparity of views' concerning 'facts' (as opposed to questions of policy) which are 'material'. In determining the question of materiality the Commission should consider whether the facts were central to the proposed rule and whether they were facts which could be proved or disproved by the accumulation of further information.

S. Rep. No. 92-269, 92 d Cong., 1st Sess. 25-27 (1971). On February 7, 1972 the House of Delegates of the American Bar Association rejected a recommendation that $S .986$ be amended to permit notice-and-comment rulemaking pursuant to section 553 of the Administrative Procedure Act. 58 A.B.A.J. 384 (1972). 


\section{Pending Consumer Product Safety Legislation.}

Another bill pending in Congress contemplates a different blend of procedures in rulemaking. S. 3419 proposes to establish an independent Consumer Safety Agency with broad power to establish safety standards for consumer products and to ban "hazardous consumer products." The new agency would assume the product safety functions of several agencies, mcluding the Food and Drug Administration. The rulemaking provisions, discussed below, closely follow an earlier proposal made by the executive branch, and appear to be relatively noncontroversial.

The procedures are set forth in detail in the bill. The agency must first publish a general notice, stating that it is considering the establishment of a standard and describing the product and the risks it is attempting to protect the public against. The notice must also give "a summary description of the information upon which the Commissioner has found a need to mitiate the proceeding," and invite offers from persons who are technically competent to develop a standard in accordance with general procedures established by the agency. ${ }^{242}$ Interested persons are invited to submit information challenging the need for the standard, propose existing standards for agency consideration, or offer to develop appropriate standards. If the Commissioner determines that a need to control a risk exists he may then develop the standard, either with his own staff or by accepting offers of private persons to develop it. ${ }^{243}$ The agency may make a financial contribution to such a person if its offer is accepted.

The agency is directed to promulgate regulations "governing the development of proposed consumer product safety standards." The regulations must include an "opportunity by imterested persons to participate in the development of such standards."244

After development of a proposed standard, the agency must publish a further notice in the Federal Register and provide an opportunity for comment. The notice must set forth the proposed standard and describe the need therefor. Further, it must include a statement as to "the manner in which interested persons may examine data and other information upon which such proposed standard ... is based."245 While the bill does not require the agency to hold an oral hearing, it contemplates that one may be held as a matter of agency

242. S. 3419, 92d Cong., 2d Sess. $§ 303$ (1972).

243. In the event an existing standard is deemed acceptable by the agency, that standard may be promulgated immediately without further proceedings.

244. S. 3419, 92d Cong., 2d Sess. $\$ 305$ (1972).

245. Id. $\$ 306(\mathrm{a})(3)$. 
discretion "for the purpose of resolving any issue of material fact."240 Before issuing a final order, the Commissioner must make "appropriate findings for inclusion in such order" with respect to a variety of matters, including the "data and comments submitted in the course of ... [the] proceeding." ${ }^{247}$

A statutory right of judicial review in specified courts of appeal is provided on the basis of substantial evidence on the record taken as a whole. The record, for this purpose, consists of the various notices published by the agency, "the transcript or summary of any proceedings and the findings arising therefrom; and any other information, including comments of interested persons, required to be considered by the Commissioner in the promulgation of such order."248

\section{Pending Medical Devices Legislation.}

Finally, H.R. $12316^{249}$ relating to the safety and effectiveness of medical devices, adopts some but not all of the provisions of S. 3419, just discussed. Offers to develop standards by private parties must be solicited and the notice must specify the available data that underlie the proposal. ${ }^{250}$ Immediate judicial review is provided for final orders establishing, amending or revoking a standard. ${ }^{251}$

Unlike S. 3419, however, H.R. 12316 makes no reference to a substantial evidence test on review, to a "public record," or to a discretionary evidentiary hearing by the agency. The bill merely states, rather ambiguously, that section 553 of Title 5 is to apply "to the extent not inconsistent with" the procedures set forth in the bill. ${ }^{262}$

\section{E. Review by Congress}

The Highway Safety Act of 1966 authorizes the Secretary of Transportation to establish uniform standards for highway safety. ${ }^{253}$ These standards are to "be developed in cooperation with the States, their political subdivisions, appropriate Federal departments and agencies, and such other public and private organizations as the Secretary deems appropriate."254 In 1970, this broad grant of rulemaking au-

246. Id. $\S \S 306(\mathrm{a}),(\mathrm{b})$.

247. Id. $\$ 306(\mathrm{c})$.

248. Id. $\S \S 310(\mathrm{a}),(\mathrm{b})$.

249. 92d Cong., 1st Sess. (1971).

250. H.R. 12316, 92d Cong., 1st Sess. $\$ 101$ (1971) amending 21 U.S.C. \& $513(c)(1970)$.

251. Id. amending 21 U.S.C. $\& 513(\mathrm{~g})(4)$ (1970).

252. Id.

253. 23 U.S.C. $\$ 402$ (a) (1970).

254. $I d . \S 402(\mathrm{e})$. 
thority was amended to provide that future uniform safety standards should not be promulgated unless submitted to Congress at least 90 days prior to the effective date. ${ }^{255}$ The legislative history indicates that this provision was a substitute for a House-passed proposal that would have totally eliminated the power to establish uniform standards except by specific statutory approval. ${ }^{256}$

A similar requirement appears in S. 986, authorizing the FTC to promulgate legislative rules defining acts or practices that are unfair or deceptive to consumers. The Bill requires that after final promulgation by the Commission of any legislative rule, the rule and a supporting brief based upon the Commission proceedings be referred to the House of Representatives and the Senate; if the rule is not disapproved within 60 days it becomes effective. ${ }^{257}$ After the expiration of the period for legislative review, preenforcement judicial review becomes available. The Committee report notes that any reviewing court should take judicial notice of congressional action, or lack thereof, and that the standard of judicial review is whether the rule is supported by substantial evidence on the basis of the entire record before the court. ${ }^{258}$

Legislative review of rules is probably less desirable than the more traditional judicial review. Of course, rulemaking of itself is administrative legislation, and abstractly, review by Congress, the delegating authority, may seem appropriate. The constitutionality of such statutes is doubtful, however, to the extent they omit approval by the President, or mvolve approval by a committee or a single branch of Congress. Further, there is no machinery for effecting such review, and the experience of legislative review of administrative or executive actions in other areas, for instance, reorganization plans, does not indicate that such review provides a full and careful reappraisal of the substantive decisions by Congress. Judicial review, with its long tradition, appears to provide a more desirable type of review of agency action.

\section{F. Provisions Making Inapplicable Parts or All of the Administrative Procedure Act}

Several recent statutes discussed above provide that parts or all of the Administrative Procedure Act are not to apply to rulemaking proceedings. Such provisions possibly are a product of legislative unhappiness with the summary procedures permitted by section 553 . They usually give rise to serious ambiguities since they leave the agency in

255. Id. $\S 402(\mathrm{~h})$.

256. 3 U.S. CoDe CoNG. \& AD. News 5481-2 (91st Cong., 2d Sess. 1970).

257. S. 986, 92d Cong., 1st Sess. $\$ 206$ (1971) amending 15 U.S.C. $\$ 46(\mathrm{~g})(2)$

(1970).

258. S. Rep. No. 92-269, 92d Cong., 1st Sess. 27 (1971). 
a limbo with no established procedures to follow. Hence, agencies have tended either to ignore them, to consider them as justification for creating a modified procedure of the type described previously, or to construe them as being inapplicable to a specific proceeding.

In at least one instance, Congress appears to have intended to create a truly summary procedure. The Water Quality Improvement Act of $1970^{259}$ contains several broad grants of rulemaking authority. A parenthetical clause appears to authorize the agency to omit the comment stage of the informal section 553 rulenaking proceedings. ${ }^{200}$

\section{G. Delegation of Rulemaking Authority to Persons Other than the Agency}

Several statutes divorce the promulgation of rules from the substantive decision as to what the rules should contain. The promulgating agency is directed by the use of the mandatory "shall" to promulgate what is approved by someone else. This division of responsibility serves any of several possible purposes: (1) it may be a device by which two agencies may cooperate on the decision whether or not to issue rules, (2) it may be a device by which rules reached through a process of mediation or negotiation by nongovernmental interests may be put into effect, or (3) it may be a device to check unlimited agency discretion.

\section{Agency Cooperation}

Little objection can be made to a division of responsibility between two agencies in connection with a single rulemaking proposal. As previously described, $\mathrm{HEW}^{r}$ and Interior share responsibility for the development of safety rules under the Federal Coal Mine Health and Safety Act; ${ }^{201}$ obviously, one agency, or the other, but not both, should do the promulgating. HEW and Justice similarly share responsibihty for the classification of drugs under the Comprehensive Drug Abuse Prevention and Control Act but the Department of Justice lias the sole

259. 33 U.S.C. $\$ \$ 1151$ et seq. (1970).

260. Section 12(b) of the Water Quality Improvement Act states: Section 551 through 559 inclusive (other than section 553(c)) and 701 through 706 inclusive, of Title 5, shall apply to regulations issued under the authority of this section.

33 U.S.C. $\$ 1162$ (b) (1970). The legislative history states only that, Section 12(b) would apply the APA provisions as now contained in Title $V$ (other than the form of administrative procedure provided in section 553 (c)) in lieu of the detailed administrative proceedings and judicial review contained in the comparable Senate provisions.

2 U.S. Cone Cong. \& AD. News 2691, 2730 (91st Cong., 2d Sess., 1970).

261. See text accompanying notes 195-205 supra. 
power to promulgate regulations. ${ }^{262}$ When a rulemaking decision requires findings or policy determinations in several different areas, a division of responsibility between agencies may be a reasonable political compromise. It is of course desirable in such a situation to specify with care the responsibility of each agency and the procedures each is to follow. ${ }^{263}$

\section{Mediation or Negotiation by Nongovernmental Interests}

If the ad hoc or non-governmental group is composed primarily of representatives of adverse interests, such as employers and employees, a requirement that the agency accept rules agreed to by such a group may reflect a kind of compulsory bargaining. The Fair Labor Standards Act ${ }^{264}$ and the Federal Metal and Nonmetallic Mine Safety Act, ${ }^{265}$ discussed in section $\Pi,{ }^{266}$ may be cited as examples of this use of delegation of authority.

\section{Check on Agency Discretion}

Finally, a division of responsibility with a non-governmental or ad loc group may reflect an attempt to place a check on unlimited agency discretion. For example, the Administrator of the Environmental Protection Agency is authorized to propose water quality standards for interstate waters ${ }^{207}$ and air quality standards under the Clean Air Act Amendments of $1970 .^{268}$ Such standards obviously may lave tremendous economic impact and apparently for this reason Congress imposed additional checks on agency discretion.

The Governor of an affected state may request a "public liearing" on water quality standards proposed by the Administrator. The learing is held before a hearing board of five or more persons, and one member is selected by each affected Federal department or agency. EPA officers or employees may be included in the learing board but agency personnel may not be a majority of the board. The recommendations of this learing board are binding on the Adinimistrator, who is directed to promulgate "revised regulations . . . in accordance with the hearing board's recommendations."269 The hearing boards

262. This statute and its administration is discussed in greater detail in section $I$. See text accompanying notes 148-160 supra.

263. The Comprehensive Drug Abuse Prevention and Control Act of 1970 imposes no procedures on HEW in resolving scientific issues [21 U.S.C. $\$ 811$ (1970)], but requires the Department of Justice to conduct a formal on-the-record proceeding.

264. 29 U.S.C. §§ 201, et seq. (1970).

265. 30 U.S.C. $\$ \S 721-40$ (1970).

266. See text accoinpanying notes 124-129 supra.

267. 33 U.S.C. $\$ 1160$ (1970).

268. 42 U.S.C. $\$ 1857 d(f)(1)$ (1970).

269. 33 U.S.C. $\$ 1160$ (c)(4) (1970). 
are required to follow trial-type procedures in establishing water quality standards. These procedures include the designation of parties, the presentation of sworn testimony, and the right to cross examme witnesses. ${ }^{270}$ Given these procedural requirements the additional provision that hearings are to be conducted "in an informal but orderly manner"271 seems, at best, hortatory.

\section{IV.}

\section{SUGgested Procedures for GeNERAL RULEMAKING}

Reflecting on the numerous statutory rulemaking provisions enacted or considered by Congress within the last few years, it seems clear that Congress has found persuasive several different objections to pure notice-and-comment ruleinaking. Articulation of these objections helps to classify these disparate and confusing statutory provisions. Five possible objections can be distinguished:

(1) An agency should not promulgate detailed rules that drastically affect certain persons without at least giving those persons an opportunity to make an oral presentation before the agency personnel having substantial responsibility for the formulation of the final rules. An oral presentation enables persons to present their views more forcefully and persuasively than an opportunity to comment in writing. Also, a dialogue may be created between members of the Agency staff and affected persons which is beneficial to everyone.

(2) Affected persons should be consulted and permitted to participate in some way in the early stages of formulating the rule itself. Reflecting this, several recent statutes require consultation by the agency with interested and affected groups; also, two bills now pending before Congress go even further and propose that agencies formally invite offers for assistance in drafting proposed rules.

(3) Factual disagreenents between the agency and affected persons should be resolved not by the agency unilaterally and summarily, but through some kind of further procedure. One possibility is to conduct a further hearing on the limited issues in dispute; such a hearing might involve soine trial-type procedures. Another possibility is to submit the issue to a committee process in which affected persons have at least a voice.

(4) Before adopting rules dealing with technical or scientific matters, the agency should be required to obtain and consider in some formal way the views of non-agency experts. Soine sort of committee, coinposed of such experts, is an obvious suggestion.

270. 40 C.F.R. $\$ \$ 104.18,104.20,106.8,106.10$ (1972).

271. Id. $\$ \S 104.14(\mathrm{c}), 106.4(\mathrm{c})$. 
(5) There should be immediate, meaningful judicial review of the factual conclusions on which the agency is proceeding when it promulgates rules.

These objections appear to explain the great bulk of the special statutory provisions discussed earlier. Of course, in the abstract, selection of a specific procedure for a specific statute requires merely the isolation of the underlying objection to simple notice-and-comment rulemaking. The actual legislative process is not so simple, however, and a variety of factors may contribute to the enactment of variant or ambiguous provisions. Legislators, concerned with the broad policy questions of proposed legislation, may tend to ignore technical procedural sections, and may be unaware that they contain serious ambiguities. Further, some of these special statutory provisions may reflect raw political power. Interested groups, too weak to block legislation entirely, may be able to affect specific provisions. Since procedural requirements often appear superficially reasonable, it may be relatively easy to add them. They may be added in the hope that they will slow the administrator down when he seeks to impose onerous restrictions on the affected industry or that these requirements may provide an additional basis for judicial review.

Moreover, legislative draftsmen do not have guidelines as to which procedural requirements are workable and which are not, and there is no generally accepted statutory language for describing specific procedures. As a result, each bill appears to be unique to some extent. Counsel within the executive branch, particularly the Office of Management and Budget and the agencies that will be charged with administering the legislation, are consulted in the drafting of legislation. This may occur at an early stage in the legislative process; however, considerable tinkering with the procedural provisions apparently occurs later.

Last, the boilerplate of new legislation (including procedural provisions) is often modeled on previously enacted statutes dealing with similar or related subjects. If the earlier statute contained ambiguous or confusing procedural provisions, they may be carried over into the new legislation. There is also a tendency, however, to tinker with the language of the earlier statute; particularly in the absence of a complete review of all its procedural provisions, changes in wording are as likely to create ambiguities as to eliminate them.

A reasonable solution to the problems created by varying and ambiguous statutory procedural requirements should do the following: First, it should reject the polar approach of the Adininistrative Procedure Act, and recoguize the existence of a variety of rulemaking procedures which may be classified as neither "formal" nor "informal". 
Second, it should urge that statutory provisions be drafted so as to clearly specify the kind of public participation and hearing procedures agencies are to follow in rulemaking. Last, it should suggest logical, consistent, and unambiguous procedures which appropriately might be considered by Congress in the future when granting rulemaking authority. The discussion which follows is directed toward the development of such procedures.

\section{A. Consideration of Outside Views and Participation of Affected Parties}

When the legislative purpose is to assure affected persons that their views and problems will be carefully considered by the agency, or to provide more meaningful participation in the formulation of the rules themselves, either or both of two procedures can be added to the simple notice-and-comment procedure without creating serious complications. One addition is that the agency be directed to hold an oral legislative-type hearing. Preferably, the hearing should be before the persons with the ultimate power of decision, but practical considerations seem to dictate that the hearing may be held before a high-ranking agency official or, when the agency head is a multi-nnembered Commission, possibly one or more of the members. When this type of hearing is held, there is little purpose in having an APA hearing examiner conduct the hearing.

An additional provision that can be added to the notice-and-comment procedure would allow the agency to create advisory committees in which affected persons and their representatives have a voice, but are not in the majority. ${ }^{272}$ Even though the notion of a committee coinposed primarily of outside experts establishing regulatory policy is superficially attractive, it is important to recognize that the function of such advisory committees is to allow participation in the rule-making process, ${ }^{273}$ not to delegate the agency's rulemaking power. However, when the legislative purpose is to cnsure that the agency will solicit

272. Some agencies, such as FDA, sometimes prefer to cloak an unpopular regulatory decision by stating that it is relying upon, or implementing, the views expressed by some impartial scientific panel or body, which presumably is more expert than the agency. The Drug Efficacy Study Implementation program (DESI) is an example. Usually this is not a completely honest posture for the agency to take, since it is charged with making the regulatory policy and must decide whether or not to accept the factual conclusions of the expert group.

273. Also, mandatory consultation between agencies appears to add little to simple notice-and-comment rulemaking. Statutes requiring an agency to "consult" with one or more other agencies before promulgating proposed or final rules appear to be designed to insure full agency consideration of possible problems and to improve the integration of various regulatory programs. The usefulness of this requirement is questionable, however. Indeed, if the consultation is im writing, it tends to become merely one agency's comment on another agency's proposal. 
and consider the views of independent, outside experts on scientific or technical questions, the obvious solution is the mandatory use of an expert advisory committee. Interested persons probably should not have direct representation on such a committee, though access to the committee either by consultation or presentation may be desirable.

Two bills recently introduced in Congress provide that the agency must solicit the assistance of private interests in developing standards. Presumably these private interests may reflect the interest of persons subject to the regulation. While there has been no practical experience with this device, it appears to be an undesirable innovation. The drafting of regulations by persons who are not entirely in sympathy with the regulatory goals may lead to watered down proposals which the agency may strengthen only at a substantial political cost. Further, an excellent way to force an agency staff to come to grips with a complex regulatory problein is to have it draft tentative regulations and submit thein to interested persons for comment; to the extent that the agency delegates this function, its staff may lose a substantial educational opportunity. It is also possible that draftsmen of complex standards may include provisions the significance of which may not be recognized by the agency.

\section{B. Creation of a Record Permitting Judicial Review}

When ineaningful judicial evaluation of the proposed rules as a check on agency use of broad rulemaking powers is desired, a procedure must be devised to create a "record" that will permit a court to review the agency action. On the other hand, the agency should not be overburdened with time consuming procedures in creating the record. The following procedures, which are partially drawn from the middle ground procedures described earlier, ${ }^{274}$ seem to be feasible.

First, the notice of proposed rulemaking should include or refer to the substantive facts and information on which the agency is relying in proposing the rule. The notice, and material referred to in the notice, should be sufficient for an interested person to determine and evaluate the factual premises on which the agency is proposing to act. Where the information is bulky, references to them should be included in the notice of proposed rulemaking, and copies should be made available by the agency. When statistical studies or surveys are used, copies of the underlying data should be made available; when confidentiality must be protected, summaries or extracts should be provided.

274. See text accompanying notes 174-271 supra. 
When books or long reports are referred to, the specific portions relied upon by the agency should be designated.

Each interested person should be invited to submit written objections, comments and documents to be included in the record, if he wishes to have them considered by the agency or court. Affidavits may be included if persons wish to controvert specific portions of the material referred to by the agency.

Further, a legislative-type oral hearing should be held before the agency head or a high ranking officer. At this hearing there should normally be argument but no cross-examination, though the presiding officer may permit questions to be asked. Participants at this hearing need not be sworn but a verbatim transcript should be made.

If it appears at the hearing that there is a genuine controversy over a fact that will materially affect the outcome of the proceeding, the agency may direct that the issue be considered either in a supplemental hearing or by an advisory committee, depending on the nature of the issue and the most effective procedure to resolve it. Any party desiring that an issue be submitted either to a supplemental hearing or to a committee should be required to specify precisely the factual issue to be considered. Broad or general requests should ordinarily be rejected out of hand. ${ }^{275}$

This supplemental hearing should be held either before an agency staff member or an APA hearing examiner. The precise procedures should not be rigidly specified in advance but should be molded on the basis of the nature of the factual issues in controversy, and how they may be most efficiently resolved. In some instances, written sub-

275. See American Airlines, Inc. v. CAB, 359 F.2d 624, 632-3 (D.C. Cir. 1966). A number of agencies have in the past denied requests for formal evidentiary hearings in rulemaking proceedings on the ground that the request does not specify the factual issues on which the hearing is to be held. Among the agencies adopting this position are the Federal Aviation Agency which, in 1971, refused to hold an evidentiary hearing to reconsider the ovcr-60 retiremeut rule for commercial pilots on the bare allegation that evidence would be offered to establish the absence of any reasonable rclationship between the regulation and air safety [36 Fed. Reg. 7153 (1971)] and the Federal Power Commission, which refused to hold an evidentiary hearing in a rulemaking proceeding relating to natural gas prices:

We have pending merely broad conceptual demands for an adjudicatorytype hearing, with broadside requests for cross-examination. None of the requests contain the specificity or the clarity required for us to evaluate their merit. Nowhere, in the requests made, is there any specific proffer as to the particular subjects that may require oral hearings of the witnesses whose sworn testimony was received, what kind of facts those that request cross-examination propose to adduce, or by which of the witnesses they propose to adduce such facts.

36 Fed. Reg. 13585, 13586 (1971). Most such requests, however, were denied on the ground that the issues did not lend themselves to a trial-type procedure. See, e.g., Domestic Public Point-to-Point Microwave Radio Service, 36 Fed. Reg. 11144 (1971). 
missions may be sufficient. On others, oral examination and crossexamination may be appropriate (for example, when the issue involves testimonial credibility or accuracy, or subjects such as patterns of drug abuse, for which docuinentary evidence is scant). In still other situations, questioning may be limited to the presiding officer.

The notion that trial-type procedures should be imposed upon rulemaking is controversial. ${ }^{276}$ It seems clear, however, that some factual issues which arise in rulemaking are best resolved through trialtype procedures; indeed several agencies have recognized this and utilized such procedures in specific instances even when not required to do so. ${ }^{277}$ As described above, even in formal rulemaking-on-a-record proceedings, the trial-type hearing has worked reasonably well in some situations. The basic problen with mandatory trial-type procedures is that they sometimes work poorly, not that they always work poorly.

As an alternative to the supplemental hearing, the factual issue may be presented to an advisory committee when the agency decides that a further hearing is inappropriate. For instance, issues involving scientific or technical questions, or questions which may be resolved

276. Two recent articles suggest that increased innovation in rulennaking procedures, including the use of trial-type procedures, might be desirable. See Robinson, The Making of Administrative Policy, Another Look at Rulemaking and Adjudication and Administrative Procedure Reform, 118 U. PA. L. REv. 485 (1970); Clagett, Informal Action-Adjudication-Rule-making: Some Recent Developments in Federal Administrative Law, 1971 DukE L.J. 51, 72-73. See also Walter Holm \& Co. v. Hardin, 449 F.2d 1009, 1015-16 (D.C. Cir. 1971) (holding that in some situations procedures in addition to those specified in 5 U.S.C. $\$ 553$ may be constitutionally required.)

Iu 1971, the Committee on Rulemaking of the Administrative Conference presented a recommendation similar to that proposed in the text. This recommendatiou was sharply reduced in coverage by the Conference, and became the largely meaningless recommendation 25, Articulation of Agency Policies. Adopted May 7-8, 1971, REPORT OF THE ADMINISTRATIVE CONFERENCE OF THE UNITED STATES 57 (July 1971).

277. A survey of agencies by the Administrative Conference revealed several instances in which agencies used trial-type proceedings on a discretionary basis in connection with rulemaking. These include:

(1) Commercial zone and similar determinations by the ICC. In these proceedings the issues were narrow and particularized-dealing with specific geographical areasand the subject of intense controversy. See text accoinpanying notes 119-123 supra.

(2) A proceeding by the FCC to determine the nature and scope of FCC jurisdiction over pole attachment agreements between cable television companies and electric utility and teleplione companies. In re California Water \& Teleplione Co., 35 Fed. Reg. 6987 (1970). The FCC directed that a trial-type hearing be lield in this proceeding "to obtain reliable factual data concerning pole attachment policies and practices." Id. at 6988. The FCC was uncertain whether formal contract documents obtained by the agency accurately reflected what was done when CATV lines were attached to utility poles.

The survey revealed other instances in which trial-type procedures were used in specific ruleinaking proceedings. In some instances, the agency was uneertain whether the procedures were legally required; in others, licensing and rulemaking proceedings were combined in a single proceeding. 
by an appraisal of readily available information could be referred to a committee. The committee should usually contain representatives of the principal points of view; but a majority should be persons expert in the area, without a direct financial interest in the proceeding. To avoid delay, the committee should be directed to file a written report with recommendation within a short period of time and a copy of the report should be included in the record of the proceeding.

If disputed factual issues are heard at a supplemental hearing or by an advisory committee, the report should be made public and interested persons should be afforded an opportunity to comment. If the report contains confidential information such as trade secrets, full publication may be impractical, but at the very least a summary or extracts should be published for comment.

In addition, the final order and decision of the agency should contain a detailed description of the facts on which the agency action is based. If a factual controversy was the subject of a supplemental hearing or was referred to an advisory committee, forinal findings by the agency should be imcluded. The final order should also discuss the contentions that were raised by affected persons and state the agency's position with respect to thein.

Finally, the final order and decision should be subject to judicial review in a specified court on a "substantial evidence of record" basis. The record should consist of the following: (1) the notice of proposed ruleunaking and the documents referred to therein; (2) the comments of affected persons and docuinents submitted by them; (3) the transcript of the oral legislative hearing; (4) the transcript of any supplennental hearing or report of any advisory committee; and (5) the final order of the agency. Since this record may be bulky because of background docuinents, books, reference manuals, and the like designated by the agency and by other participants, it may be desirable to restrict the record to only those parts of background documents that are designated by the agency or by a participant. An obvious analogy is the system used by the United States Supreme Court to limit the portions of bulky transcripts actually considered by the Court.

\section{CONCLUSION}

Professor Davis has stated that the notice-and-comment procedure of administrative rulemaking is "one of the greatest innovations of modern government."278 Perhaps so. Notice-and-comment rulemaking is efficient and flexible, and permits the agency to shape procedures to

278. K. Davis, Administrative Law Treatise, $\S 6.15$ at 283 (Supp. 1970). 
fit the particular problem before it. The difficulty is that many participants in the legislative process are not persuaded, and as a result additional procedural requirements continue to be imposed on administrative rulemaking. Despite the theoretical advantages of notice-andcomment rulemaking, a real need exists to evolve procedures which are fair and efficient and which stand a reasonable chance of legislative acceptance. 


\section{California Law Review}

\begin{tabular}{lll}
\hline Vol. 60 & SEPTEMBER 1972 & No. 5 \\
\hline \hline
\end{tabular}

\section{BOARD OF EDITORS}

Notes \& Comments

KEVIN F. KeLLY

WIIIIAM F. CAPPS

Crayo H. Casebeer

MARK S. DODSON

ANN HASSE

LESLIE ANN JOHNSON

Projects

JEFFREY M. ALLEN

JosePH P. DiCIUCcio

Susan Frelich Appleton ALICE M. BEAsLeY MrChael J. BERTINeTtI RAYMOND A. DIAZ PAUL E. DORROH KENNETH J. Fishbach JR. ERNESTINE FORREST HOWARD W. Foss JR.
Editor-in-Chief

STEPHEN L. KosTKA

Managing Editor

STEPHEN J. YODER

Managing

GABRIELLE R. CAMPBELL

JAMES DRUMMY

Peter Grossman

Associate Editors

David M. Giass

KELLY GUEST

JACK H. KAUFMAN JR.

LARY LAWRENCE

DANIEL J. LEER

CAMILLE E. LEGRAND

Administrative Assistant

PATRICIA G. SMITH
Articles \& Book Reviews

Ira MARK ElLMAN

MICHARL J. BARER

Marsha Siegel Berzon

DAVID F. BOYLE

Supreme Court

PALMER BROWN MAdDEN

Research

Steven H. Beli

RIChaRd Kalish

Charles H. Matthews Jr

Crato D. Miller

RAYMOND D. PIKE

THOMAS E. RANKIN

Lee Charles Rosenthal

Craig M. Thomas

Martin J. Thompson

Jomn E. THORSON 